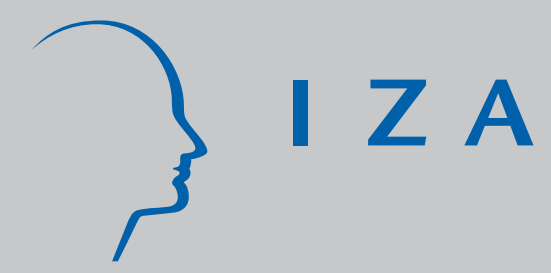

IZA DP No. 5152

Health Outcomes and Socio-Economic Status among the Elderly in China: Evidence from the CHARLS Pilot

John Strauss

James P. Smith

Xiaoyan Lei

Albert Park

Zhe Yang

Yan Shen

Yaohui Zhao

August 2010 


\section{Health Outcomes and Socio-Economic Status among the Elderly in China: Evidence from the CHARLS Pilot}

\author{
John Strauss \\ University of Southern California \\ Xiaoyan Lei \\ Peking University and IZA \\ Albert Park \\ Oxford University and IZA
}

\author{
James P. Smith \\ RAND Corporation and IZA \\ Zhe Yang \\ Peking University \\ Yaohui Zhao \\ Peking University and IZA
}

\author{
Yan Shen \\ Peking University
}

\author{
Discussion Paper No. 5152 \\ August 2010 \\ IZA \\ P.O. Box 7240 \\ 53072 Bonn \\ Germany \\ Phone: +49-228-3894-0 \\ Fax: +49-228-3894-180 \\ E-mail: iza@iza.org
}

Any opinions expressed here are those of the author(s) and not those of IZA. Research published in this series may include views on policy, but the institute itself takes no institutional policy positions.

The Institute for the Study of Labor (IZA) in Bonn is a local and virtual international research center and a place of communication between science, politics and business. IZA is an independent nonprofit organization supported by Deutsche Post Foundation. The center is associated with the University of Bonn and offers a stimulating research environment through its international network, workshops and conferences, data service, project support, research visits and doctoral program. IZA engages in (i) original and internationally competitive research in all fields of labor economics, (ii) development of policy concepts, and (iii) dissemination of research results and concepts to the interested public.

IZA Discussion Papers often represent preliminary work and are circulated to encourage discussion. Citation of such a paper should account for its provisional character. A revised version may be available directly from the author. 


\section{ABSTRACT \\ Health Outcomes and Socio-Economic Status among the Elderly in China: Evidence from the CHARLS Pilot ${ }^{*}$}

We are concerned in this paper with measuring health outcomes among the elderly in Zhejiang and Gansu provinces, China, and examining the relationships between different dimensions of health status and measures of socio-economic status (SES). We use the China Health and Retirement Longitudinal Study (CHARLS) pilot data to document health conditions among the elderly in Gansu and Zhejiang provinces, where the survey was fielded. We use a very rich set of health indicators that include both self-reported measures and biomarkers. We also examine correlations between these health outcomes and two important indicators of socioeconomic status (SES): education and log of per capita expenditure (log pce), our preferred measure of household resources. While there exists a very large literature that examines the relationships between SES and health measures, little has been done on Chinese data to see whether correlations reported in many other countries are replicated in China, particularly so for the aged. In general education tends to be positively correlated with better health outcomes, as it is in other countries. However, unmeasured community influences turn out to be highly important, much more so than one usually finds in other countries. While it is not yet clear which aspects of communities matter and why they matter, we set up an agenda for future research on this topic. We also find a large degree of under-diagnosis of hypertension, a major health problems that afflicts the aged. This implies that the current health system is not well prepared to address the rapid aging of the Chinese population, at least not in Gansu and Zhejiang.

JEL Classification: $\quad 110$

Keywords: health, China

Corresponding author:

James P. Smith

RAND

1776 Main Street

P.O. Box 2138

Santa Monica, CA 90407

USA

E-mail: smith@rand.org

\footnotetext{
* Comments from Richard Suzman and David Weir are greatly appreciated, as are suggestions from two referees and the Editors. Earlier versions were presented at the annual meetings of the Population Association of America, April 2009, Detroit, the World Congress of the International Association of Gerontology and Geriatrics, July 2009, Paris, and the $2^{\text {nd }}$ International Conference on Health and Retirement in China, July 2009, Beijing. This research was supported by grants from the National Institute of Aging, the China National Natural Science Foundation and the World Bank, China.
} 


\section{Introduction}

We are concerned in this paper with measuring health outcomes among the elderly in Zhejiang and Gansu provinces, China, and examining the relationships between different dimensions of health status and measures of socio-economic status (SES). China has undergone a health revolution over the past 50 years, with life expectancy having risen from 46 in the 1950s to just over 71 in 2000 (Wagstaff et al., 2009; World Health Organization, 2009). Driving this change, under 5 mortality fell dramatically from 225 per 1,000 live births in 1960 to 64 in 1980 to 22 in 2007 (Wagstaff et al., 2009; UNICEF, 2009). Most of this decline was due to an increasing control over infectious disease and under-nutrition. As a result, infectious diseases have been progressively replaced by chronic diseases as the major source of ill-health and mortality (Hossein, 1997; Lopez et al., 2006).

As China has been passing through its health transition, it has also been undergoing a nutrition transition, which has both good and bad sides (Popkin et al., 1993, 1995a; Popkin, 1999, 2002). Among the principle dimensions of this transition has been a dramatic rise in body mass index among adults and a large change in diet towards more fatty foods (Popkin et al., 1995b). For instance Luo (2003), using the China Health and Nutrition Survey (CHNS), documents an increase in overweight for adults over 20 years from 1989 to 1997; for women from $11 \%$ to $21 \%$ and from $6 \%$ to $17 \%$ for men. ${ }^{1}$ At the same time, Luo shows that the fraction of adults elderly who are undernourished (a BMI under 18.5) has fallen, particularly so for those over 60 years, from 19\% to 13\% for women and 20\% to 12\% for men, from 1991 to 1997 .

Related to the health and nutrition transitions has been China’s demographic transition. China's elderly will increase from under $10 \%$ of the total population in 2000 to $30 \%$ in 2050

\footnotetext{
${ }^{1}$ Overweight is defined using World Health Organization standards of having a BMI 25 or above.
} 
(Kinsella and He, 2009). The number of workers per pensioner has already fallen from over 12 in 1980 to 2 in 2005. This sharp demographic transition is likely to place stress on China's health system, which has been focused on disease at younger ages and on infectious, not chronic diseases.

In this paper, we use CHARLS pilot data to document health conditions among the elderly in Gansu and Zhejiang provinces, where the survey was fielded. We use a very rich set of health indicators that include both self-reported measures and biomarkers. We also examine correlations between these health outcomes and two important indicators of socio-economic status (SES): education and log of per capita expenditure (log pce), our preferred measure of household resources. While there exists a very large literature that examines the relationships between SES and health measures, little has been done on Chinese data to see whether correlations reported in many other countries are replicated in China, particularly so for the aged. While we cannot infer causality from these estimates, they tell us something important about the degree of health differentials by education and pce.

In general education tends to be positively correlated with better health outcomes, as it is in other countries. However, unmeasured community influences turn out to be highly important, much more so than one usually finds in other countries. While it is not yet clear which aspects of communities matter and why they matter, we set up an agenda for future research on this topic. We also find a large degree of under-diagnosis of hypertension, a major health problems that afflicts the aged. This implies that the current health system is not well prepared to address the rapid aging of the Chinese population, at least not in Gansu and Zhejiang. 
This paper is divided into five sections. The next section briefly introduces the topic, Section 3 describes the data in while our main empirical findings are presented in section 4 . The final section highlights our main conclusions.

\section{Health-SES correlations}

Across most country settings, no matter which measures of SES are used (income, wealth or education), the evidence that this association is large and pervasive is abundant (Marmot 1999, Smith 1999, Strauss and Thomas, 1998).

Mainly due to the absence of high quality data, far less research has been conducted on the magnitude and reasons for the SES health gradient in China. China is about to age very rapidly and has at the same time been experiencing high but very unequal rates of economic growth. The extent to which this recent economic growth has improved the overall health of the Chinese population depends in part on understanding in the Chinese context the influence of economic well-being on health. Similarly, the degree to which growing inequalities in levels of economic resources in China are producing similarly large inequalities in health requires better understanding.

Part of the reason for a lack of any substantial research on this topic in the Chinese context is that until recently data in China were simply not up to the task or were largely unavailable to scholars either inside or outside China. Fortunately, this situation is changing. The investigators on this research project have been involved in a key ongoing data collection effort— the Chinese Health and Retirement Longitudinal Survey (CHARLS)—that aims to remedy this situation. 
This paper documents in detail the nature of the SES health gradient in Gansu and Zhejiang. The analysis spans many salient measures of health status - including chronic conditions, general health status, subjective measures of health, body mass index (BMI), hypertension, cognition, and functional measures of disability. In addition to standard measures of economic status widely used in other country settings, notably schooling, we examine a measure of income, household consumption, which is arguably a much better index of economic well being in a country at the level of economic development that China now has, especially in more rural regions.

The salient nature of the SES-health gradient is not difficult to document. In most countries, at each age those in higher income or wealth groups are in much better health. These differences are quantitatively large. In the US the fraction reporting excellent health among the highest income quartile is 40 percentage points higher than those in the lowest quartile (Smith, 1999). The health-income gradient widens until around age 50 after which it gradually contracts. Similar gradients of this magnitude appear in many other countries so that the US is not unique. While there is a broad consensus about the 'facts', the interpretation of underlying forces creating a strong SES health gradient and how their relative importance varies across countries at different levels of economic development are controversial.

A basic question in any country is whether differences in health by SES indicators such as education, income, and wealth largely reflect impacts from SES to health. Medical scientists often conclude that the dominant pathway is that variation in SES produces large health disparities; their main debate is about why lower economic status leads to poor health (Marmot 1999). Important insightful contributions by such scholars has involved investigating the influence of other factors besides access to high-quality health care or deleterious personal 
behaviors, both of which are believed to offer incomplete explanations. These contributions have emphasized long-term impacts of early childhood or even inter-uterine environmental factors (Barker, 1997), the cumulative effects of prolonged exposures to individual stressful events (Seeman et al., 1997), or reactions to macro-societal factors such as rising levels of income inequality (Wilkinson, 1996).

This view that the principal direction of causation flows almost exclusively from SES to health has been challenged (Cutler and Lleras-Muney, forthcoming; Lleras-Muney, 2005; Smith, 1999; Strauss, 1986, 1993; Strauss and Thomas, 1995, 1998, 2008; Thomas and Strauss, 1997, Thomas, 2010). The best evidence is in fact that causation goes in both direction, from SES to health and health to SES.

Moreover, many omitted variables determine both health measures and SES. A good example, the subject of much recent research, is health when very young, which appears to affect health in older ages, but also SES outcomes such as education and incomes as adults, in particular (Barker,1994; Gluckman and Hanson, 2005 ; Hoddinott et al., 2008; and Maluccio et al., 2009). The latter two, experimental, studies, document that nutritional supplements given to children before 3 years of age in Guatemala were associated with more completed schooling by the time they are adults, as well as higher adult labor force earnings. And yet, recent careful studies such as Lleras-Muney (2005) have established that the influence of SES on health status is in part causal.

With these caveats, it is still of much interest to examine the health-SES gradients. As discussed, these correlations will also indicate the degree of socio-economic inequalities in health outcomes and their relationships to inequality in SES, education and resources in 
particular. Income inequality is now of much policy interest. Health inequality is likely to be of policy interest as well in China, as it is in industrial countries.

\section{Data and Empirical Specifications}

We use the CHARLS pilot data, which is described in detail in Zhao et al. (2009). CHARLS was designed after the Health and Retirement Study in the US as a broad-purposed social science and health survey of the elderly in Gansu and Zhejiang provinces. The pilot survey was conducted in July-September 2008. The CHARLS pilot sample is representative of people aged 45 and over, and their spouses, living in households in Gansu and Zhejiang provinces.

Zhejiang province is located in the developed coastal region, and Gansu, in the less developed western region. Gansu is the poorest and one of the most rural provinces in China, with per capita income less than half of Zhejiang province and 75\% of the population being rural. On the other hand Zhejiang is one of the most dynamic and richest provinces, with a per capita income 50\% higher than the Chinese national average. Zhejiang has not always been so rich, but has had much faster economic growth over the past 25 years, with a strong and relatively large private sector, based on small-scale industry, and export orientation. The pilot chose these two provinces to get at extremes within China. The full CHARLS will be national in scope and is scheduled to be fielded in spring 2011.

The CHARLS pilot data represent some major advantages over existing Chinese data. Many Chinese datasets are not publicly available, though they may be available to some with special connections. The Survey of the Aged Population, which started as a cross-sectional survey and now has a small panel component, is one example. The 2002 Nutrition and Health Survey, a specialized health survey of the entire population patterned after NHANES, is another. Even if 
they were made public, both have only very scant economic information (e.g., no consumption, poor income, and wealth data) with which to examine SES-health relationships, a problem with other data sets.

The Chinese Longitudinal Healthy Longevity Survey is publicly available. It began as a survey of the oldest old (over 80 years), although younger cohorts have been added in recent years. Yet it, too, is far different from an HRS-style survey, particularly in its lack of economic variables such as consumption, income, and wealth. In addition, there were few biomarkers collected in the earlier waves. Likewise the World Health Organization's Study on Global Aging and Adult Health (SAGE), a series of global surveys on the aged, including one for China, is rather light on socio-economic information such as on incomes, wealth, retirement and family support.

Finally, the China Health and Nutrition Survey (CHNS) may be the best known household survey on China to the outside world, and has been the workhorse for many scholars. However there are important differences from an HRS survey. CHNS is not strictly an aging survey, and its sample of elderly is small. Income is also not measured well in CHNS and there are no total consumption data (only food consumption). Moreover, CHARLS has richer health data, particularly on biomarkers. Very importantly for this study, CHARLS has available numeric codes for primary sampling units, so that community fixed effects regressions may be run. CHNS does not release community codes with its data.

Hence for our purposes, CHARLS represents a major improvement for the study of health-SES relationships of the elderly in China, and it is publicly available! ${ }^{2}$

The CHARLS pilot sample was drawn in four stages. In each province, all county-level units were stratified by whether they were urban districts (qu) or rural counties (xian), and by

\footnotetext{
${ }^{2}$ See http://charls.ccer.edu.cn.
} 
region within each classification. Both urban districts and rural counties can contain both urban and rural communities, but the concentration of urban and rural populations is quite different in the two. With a goal of sampling 16 county-level units per province, the number of counties to be sampled in each stratum was determined based on population size. Before the pilot survey, the Beijing CHARLS Office first obtained a list of county units and their populations in each of the provinces from official statistics. Counties were randomly selected within each stratum with probabilities proportionate to size as measured by population.

After the county units were chosen, the National Bureau of Statistics helped us to sample villages and communities within county units using recently updated village level population data. Our sample used administrative villages (cun) in rural areas and neighborhoods (shequ), which comprise one or more former resident committees (juweihui), in urban areas as primary sampling units (PSUs). We selected 3 PSUs within each county-level unit, using PPS (probabilities proportional to size) sampling. Note that rural counties contain both rural villages and urban neighborhoods and it is also possible for urban districts to contain rural administrative villages.

In each PSU, we sampled dwellings from our sample frame. The frames were constructed based on maps prepared by CHARLS advance teams with the support of local informants. For rural villages, in many cases the lead persons on the advance teams were able to use maps drafted for the agricultural census in 2006 as a starting point and then updated them in consultation with local leaders. For urban communities, existing building maps were frequently used as the basis for the frame. All buildings in each PSU were numbered, and dwellings within each building were listed and coded using standardized methods. The advanced team verified 
that all buildings in the PSU had been properly identified, and that dwelling units within multidwelling buildings had been correctly coded before choosing the sample of households.

Once the sampling frame for a PSU was completed and entered into the lead person's computer, a CAPI (computer assisted personal interview) program was used to sample households and to conduct the interviews using laptops. The number of households sampled was greater than the targeted sample size of 16 households per PSU in anticipation of non-response and sampled households' not having any members aged 45 or older. The number of households sampled was 36 in urban PSUs and 30 in rural PSUs. We interviewed all age-eligible sample households in each PSU who were willing to participate in the survey, ultimately interviewing 1,570 households containing 2,685 respondents aged 45 and over and their spouses. ${ }^{3}$

In this paper we use data on all respondents 45 year of age and older, ${ }^{4}$ some 2,238 respondents. Tables and figures are weighted using individual sample weights. ${ }^{5}$ All figures are nonparametric and drawn using LOWESS. Regressions are run unweighted. The sampling scheme is independent of our health variables (depending only on region and urban/rural area within the province) so weights are not needed to correct for any bias from the sampling. Of course refusals can cause bias. Given that a household participates, virtually all sampled respondents do as well for the main questionnaire (Zhao et al., 2009). For the biomarkers there

\footnotetext{
${ }^{3}$ The contact and interview rate was $86 \%$ of those households that were chosen to be sampled. This is much better than HRS-type surveys in the US and Europe, which now tend to be in the 60 or even 50 percent range, and compares favorably with other surveys done in Asia.

${ }^{4}$ Spouses who are under 45 years old are dropped from this analysis.

${ }^{5}$ Here we use the sample weights allowing for household non-response using local community dummies to predict household nonresponse. We do not incorporate non-response for the biomarkers in the weights. The results using weights that do so using inverse probability weights (IPW) are similar in nature. Incorporating non-response with IPW requires an assumption of selection on observables, which is very strong and unlikely to be met. Using more standard selection methods is best using exclusion restrictions, which we do not plausibly have.
} 
is nonparticipation, but we do not feel that we have any plausible instruments to use methods such as inverse probability weighting or more standard selection methods.

In this paper, the data collected in module $\mathrm{C}$, on health outcomes, and on biomarkers are used extensively. Specifically our health measures include body mass index (BMI), hypertension and under-diagnosis of hypertension, activities of daily living (ADLs), instrumental activities of daily living (IADLs), the CES-D 10 index of depression, a cognition measure (word recall), survival expectations to age 75 (for those aged 65 and under), a general health measure and an indicator of current smoking. ${ }^{6}$ CHARLS also collected dried blood spots, which are being analyzed for C-reactive protein and hemoglobin, but those assays have not yet been completed, so are not considered in this paper.

In our regressions we start in column 1 with dummies for age group and education levels and a linear spline in log of per capita expenditure. For the dummies, being age 45-54 and having no schooling are the omitted groups. In addition to life-cycle progression, these age dummies will also capture birth year cohort effects. With only a cross-section, we cannot distinguish the two. ${ }^{7}$

Education may proxy for many factors. Since we are controlling for an income measure, education will capture factors over and above income. These will include allocative efficiency effects, which may represent better educated women having better information and their better understanding of what health inputs to choose to ensure good health (Schultz, 1984). Of course

\footnotetext{
${ }^{6}$ Heights were measured using a lightweight SECA aluminum height board, the SECA 214 portable stadiometer. Weights were measured using a portable digital scale, the Beaver Tech HTS7270. Blood pressure was taken with a digital meter, the Omron HEM 712c meter.

${ }^{7}$ Cohort effects would arise because younger birth cohorts have more schooling and also faced better health conditions when they were babies and in the fetus, compared to older cohorts. There is an accumulation of evidence now that better health conditions when young are associated with better health in old age (for instance Barker, 1994; Gluckman and Hanson, 2005; and Strauss and Thomas, 2008, for an economist's perspective).
} 
education will also be correlated with preferences towards health perhaps in part due to more forward looking behavior (Fuchs, 1982). Since past health (which would be endogenous) is correlated with current health and is an omitted variable in our analysis, it may be that past health "caused" in part education attainment, so that causation is going in both directions with crosssectional data, as we use. ${ }^{8}$

For household resources, as noted, we use log of per capita expenditure (log pce) for the household. This is a better measure of long-run resources than is current income, particularly so in low-income rural settings, where incomes can vary so much year to year because of weather variation, variation in pests, plant diseases, and so on. PCE includes the value of food production which is self-consumed, which ought to be included in income, but may not be in all measures of income. PCE also tends to be measured with less error than income (Deaton, 1997). Because income impacts may be highly nonlinear, even when pce is in logs, we use a linear spline around the median log pce. ${ }^{9}$

Since location dummies are so important to our story, we discuss them in more detail. In our first specification we do not include any location variables, just age, schooling dummies and pce. In our second specification we add dummies for province and rural residence within province. ${ }^{10}$ Clearly this is a coarse definition of location. The third specification uses a much finer definition, the PSU, which amounts to PSU, or community, fixed effects. We have one

\footnotetext{
${ }^{8}$ We tried a specification with interactions between level of schooling dummies and age to help get at causality (see Witoelar, Strauss and Sikoki, 2009, for such an exercise for Indonesia), but except for IADLs, these were generally not significant.

${ }^{9}$ A linear spline allows different slopes to the left and right of the knot point with the two lines being joined at the knot point. The first coefficient reported is the slope to the left of the knot point and the second coefficient is the change in the slope between the two knot points..

${ }^{10}$ The rural definition we use in this paper is the National Bureau of Statistics (NBS) definition. Some of the NBS urban communities are in fact rural in nature and many of their populations are farmers with agricultural hukou.
} 
dummy variable for each PSU, minus one of course. As noted in the discussion of the sampling, our PSUs are either administrative villages or urban neighborhoods, there are 92 of them in the sample. ${ }^{11}$ These PSUs are small areas that are likely to be more homogeneous than cities or counties, or certainly than province. The idea here is that each community has factors that will affect health outcomes that are not captured by the provincial dummies interacted with rural or urban area. These factors will include health care prices, inherent healthiness of the area, public health infrastructure and other factors. F-tests for all combinations of dummy variables are reported as well.

Throughout this paper, we use ordinary least squares for continuous dependent variables and linear probability model (LP) for binary dependent variables. LP model estimates are consistent for estimating average partial effects of the regressors, which is our main interest. Robust standard errors of the regression coefficients are computed, that also allow for clustering at the community level. By using robust standard errors for the linear probability regressions, we ensure that these standard error estimates are consistent (Wooldridge, 2002).

Table 1 displays unweighted means and standard deviations, clustered at the community level, for the variables used in the regressions. ${ }^{12}$ Mean respondent age is approximately 60 years, while most respondents are between 45 and 64. Women tend to be slightly younger on average because when they are chosen in the sample as a spouse, not a main respondent, they will tend to be younger than their husbands. Education tends to be low, especially for women,

\footnotetext{
${ }^{11}$ In a few cases there was no variation in the dependent variable among observations within the PSU. In these cases we refined the PSU to be a more aggregate area, usually the county or city.

${ }^{12}$ Since sample size differs depending on the health measure used, we compute means of the independent variables for the ADL sample, which is the largest, at 1,250 men and 1,225 women. For each dependent variable we use the actual regression sample; see the regression tables for sample sizes for each. Sample sizes will differ because of missing observations. For the biomarkers, such as blood pressure, some $30 \%$ of the sample were not measured. This can be because the elder person was too frail or a younger aged person was working and not able to be measured. As noted above, this corresponds with the experience of the HRS and related surveys.
} 
for whom over $60 \%$ have no schooling. Even for men, nearly half of the sample did not complete primary school, though the fractions that did complete primary and junior high school and above are much higher for men. In Gansu, the sample is two-thirds rural, while in Zhejiang just over half are urban.

\section{Results}

\section{BMI}

We first examine body mass index (BMI), which is measured as weight (in $\mathrm{kg}$ ) divided by height squared (in meters). Extreme values of BMI may be related to hypertension, diabetes and in general to higher adult mortality (Waaler, 1984). Across countries, the BMI distribution is shifted to the right for countries with higher incomes. Figure 1, which is reproduced from Strauss and Thomas (2008), demonstrates this, showing nonparametric relationships between BMI and years of schooling, for men and women aged 25-70 from 6 countries, ranging in GDP from Bangladesh to the United States. ${ }^{13}$ China as of 1991 is included among these six countries and is closest in its BMI distribution to Indonesia. Note that for men, except in the US, BMI rises with more education. For women the story is quite different. Again, the US excepting and also for low levels of schooling for women, BMI rises with education, but at higher levels, it falls. Bangladesh is an exception, BMI rises with female schooling, probably because women are still so close to levels of undernutrition. In the other developing countries, including China, the inverted U-shape relation is apparent. It may be that at higher levels of female schooling, women recognize the health benefits of reducing their BMI. Why not men is a key question for future research.

\footnotetext{
${ }^{13}$ The sources are the Matlab Health and Socioeconomic Survey, 1996; the China Health and Nutrition Survey, 1991; the Indonesia Family Life Survey, 2000; the South African Demographic Health Survey, 1998; the Mexican Family Life Survey, 2002 and the NHANES3 (National Health and Nutrition Examination Survey III), 1988-1994.
} 
Table 2 shows mean BMI by age and sex group, as well as the fraction undernourished and overweight in each group. Overall 33\% of women are overweight compared to $22 \%$ of men. The fact that a higher fraction of women are overweight compared to men is a common result found in many other countries (see Straus and Thomas, 2008). Nearly 40\% of women aged 5564 are overweight, although one has to be careful because with a cross-section it is not possible to distinguish age from birth cohort effects. BMI tends to fall with age, though again, this most likely represents birth cohort effects as well. The proportions that are overweight compare quite closely with the elderly in Indonesia (see Witoelar et al., 2009). Note too that underweight is still a problem, and particularly so for the very elderly, those 75 years and over, for whom approximately $20 \%$ are underweight.

Figure 2 displays a nonparametric locally-weighted scatterplot (LOWESS) regression plot of BMI against own education with the CHARLS data. ${ }^{14}$ The plot mimics Figure 1 closely. For men, BMI rises monotonically with levels of education, while women have an inverted Ushape pattern. If we examine the prevalence of underweight and own education the relationship is monotonically negative for women and U-shaped for men (figure available upon request). For overweight, the relationship is very similar to that for mean BMI.

Table 3 presents selected BMI regressions for men and women. BMI declines for men over 65 years and women over 75, which could be an age or a birth cohort effect. Own education is not statistically significantly correlated (at standard levels) ${ }^{15}$ with BMI for men, though it is positively correlated for women. For women education coefficients display the inverted-U pattern seen in Figure 1. The coefficients are positive though not significant at

\footnotetext{
${ }^{14}$ All figures use a bandwidth of .75 .

${ }^{15}$ We use standard levels of significance to mean a probability value of .05 or less.
} 
standard levels for can read and write, and rise in magnitude and become significant for completed primary, but then fall to near zero for junior high and above.

PCE is strongly, positively related to BMI for men, with p-values less than .05 in all cases, and less than .001 except for when community fixed effects are added. For women, pce is only weakly related to BMI. Notice that for men and women, the coefficient on pce for low levels drops roughly in half once community fixed effects are added. This is a pattern that we will see consistently throughout these results. Evidently something about the community is strongly correlated with household pce. Rural and province rural/urban dummies are significant for both men and women, as are the community dummies in the community fixed effect models. $^{16} 17$

\section{Hypertension and its under-diagnosis}

Respondents who had biomarker measurements were measured three times for blood pressure. We take the mean of systolic and diastolic measurements separately and then form a variable for being hypertensive if the mean systolic is 140 or greater or the mean diastolic is 90 or greater. These are the conventional cutoffs for high blood pressure, or hypertension. Also persons who report that they have been diagnosed with hypertension by a doctor are classified as hypertensive, including those who take medications for hypertension. ${ }^{18}$ Figure 3 shows that

\footnotetext{
${ }^{16}$ With community fixed effects, testing the joint significance of the community dummies is not straightforward. Because there are in our case few observations per cluster, we cannot cluster the standard errors after estimation using community fixed effects and use an F-test to test for the joint significance of clusters (Wooldridge, personal communication). To test the community dummies we reestimate the model with community dummies and just robust standard errors, without clustering, and do the F-test.

${ }^{17}$ It could be that the significance of the community dummy variables represents the impact of province and rural/urban location. This is not the case for our results. When we stratify the sample by the two provinces and run separate regressions for each province using community fixed effects within each province, the community dummies are still generally significant. Results are available upon request.

${ }^{18}$ Because of the way the questionnaire is designed, those who report taking medicines are a subset of those who report a positive doctor diagnosis.
} 
women are more prone to be hypertensive than are men at all ages, and that hypertension is strongly increasing with age for both genders. Overall almost half of women and $40 \%$ of men over 45 years are measured to have hypertension, but among those over 75 , almost 2/3 of men and over $3 / 4$ of women are hypertensive.

Table 4 displays the regressions predicting being hypertensive for men and women respectively. For men and women, only age and community dummies are significantly related to hypertension. There are no schooling or income effects. It is a bit surprising perhaps that hypertension is not related to SES in the CHARLS data. It turns out the same is true for the IFLS data for Indonesia. Both contrast to the US and England where studies have shown a negative correlation between education and hypertension (Banks et al., 2006).

Hypertension turns out to be a good example of the high degree of under-diagnosis of disease among the elderly in Gansu and Zhejiang. In addition to taking actual measurements of blood pressure, each respondent was asked if a doctor has diagnosed them with a series of chronic diseases or conditions, including hypertension. Hypertension is the most prevalent of the conditions that respondents report having been diagnosed, at over $25 \%$ for women and over $20 \%$ for men. If a respondent answers yes, we ask a series of follow-up questions including whether they are currently taking medications. Respondents who are taking medications may not measure above the hypertensive diagnostic threshold if the medication is working well. To arrive at a complete list of people who are hypertensive, we add to those whom we measure as hypertensive, those who report being diagnosed by a doctor but whom we did not measure as being hypertensive. We then calculate the proportion of those who are hypertensive who report not being diagnosed. 
Our results are shown in Table 5 . Some $47 \%$ of men and $42 \%$ of women are estimated to be under-diagnosed by this method. This seems quite large, although estimates for Indonesia are much higher, 74\% for men and 62\% for women (Witoelar et al., 2009) and estimates for Mexico from the Mexican Family Life Survey are also high (see Parker, Teruel and Rubalcava, 2010). One interpretation is that the health system in China, at least in Zhejiang and Gansu, are not yet set up to focus on chronic conditions of the elderly, perhaps because the emphasis is on infectious disease and on children and mothers. Additional research will be required to examine this issue more properly.

In addition to undiagnosed disease, another key health issue is good adherence to treatment when the disease is diagnosed (Goldman and Smith, 2002). Table 5 also shows that $71 \%$ of men and $80 \%$ of women who have hypertension by our definition, and report having been diagnosed, are taking medications. Thus conditional on being diagnosed a preponderance of respondents are taking medications. However, those who are undiagnosed are not.

In Table 6, using the sample of men and women who have measured or self-reported diagnosis of hypertension, we regress a dummy of not being diagnosed on the same set of covariates used in the other regressions. For men, being over 55 makes it less likely to be underdiagnosed. Having junior high school or more education is negatively related to under-diagnosis and weakly significant (at the 10\% level), although the education dummies jointly, are not significant. PCE is not significant either. These results imply that personal attributes appear not to be the principal drivers of undiagnosed disease.

The community fixed effects and province-rural/urban dummies are, however, strongly jointly significant. For women, however, the education dummies are negatively related to underdiagnosis and are jointly significant in all specifications except when we add the community 
fixed effects. Again, as for men, community dummies are jointly significant at standard levels of statistical significance. These strong community effects imply that is something about the community that is driving the degree of under-diagnosis, though in the case of women, having more education makes under-diagnosis of hypertension less likely. This is arguably an allocative efficiency effect of schooling on health probably due to better educated women going to the doctor more often, because they have the health knowledge to do so (see for instance, Schultz, 1984; Thomas et al., 1991), though we cannot test that directly.

\section{ADLs and IADLs}

Some $8.7 \%$ of men and $12 \%$ of women report having trouble with at least one activity of daily living (ADL) and 17.8\% of men and 31.3\% of women report having difficulty with at least one instrumental activity of daily living (IADL). ${ }^{19}$ Not surprisingly, these proportions rise strongly with age. Figures 4 and 5 display non-parametrically by education level, the average number of ADLs and IADLs that men and women report having difficulties in performing. For both ADLs and IADLs, the mean number that respondents have difficulty with declines with higher schooling.

Regressions for the number of ADLs and IADLs that men and women report having difficulties in performing are reported in Tables 7 and 8. For both men and women, age group dummies are significant for both ADLs and IADLs. Respondents in Gansu, the poor rural province, report more .2 extra ADLs with which they have trouble.

\footnotetext{
${ }^{19}$ Our physical activities and ADL assessments include: walking for 100 meters; stooping, kneeling, crouching; extending arms above shoulder level; lifting weights like a heavy bag of groceries; picking up a small coin from a table; climbing several flights of stairs without help, to stand from sitting position without help, dressing without help; bathing or showering; cutting food and eating; going to the bathroom without help (including sitting down and getting up); controlling urination and defication; and getting into and out of bed. The IADL assessments are having difficulties with doing household chores; preparing hot meals; shopping for groceries; managing money; making phone calls (if they have a phone) and taking medications.
} 
Once again, community dummies are jointly significant. Interestingly education and pce are not significant for either men or women for ADLs. For IADLs the results are quite different. Now education and pce are both significantly correlated, negatively with the number of IADLs. In the case of men, a little bit of schooling (knowing how to read or write, but less than completing primary school) is enough to get this impact; more schooling than that does not add any more protection. For women, schooling levels above knowing how to read or write is a bit helpful, but not much. Once again the big jump is for knowing how to read and write. PCE is negative and significant and is apparently linear in its relationship. However, once the community fixed effects are added, these coefficients fall in half and are no longer significant for men, and barely so for women.

\section{Depression}

As a measure of mental health, respondents were administered a self-reported depression scale from the short 10 question version of the CES-D (Center for Epidemiological StudiesDepression) scale, one of the major international scales of depression used in general populations. Higher scores on the CES-D scale indicate a greater likelihood of having depression. $^{20}$ While some recent studies have failed to find a relationship between depression and education or income (see Das, Do, Friedman, McKenzie and Scott, 2007, for a review of several recent studies sponsored by the World Bank), other studies have found negative correlations between education or income and CES-D scores (for example, Patel and Kleinman, 2003, and Lee and Smith, 2008). Of course at least for income, these studies may not show

\footnotetext{
${ }^{20}$ The answers for CES-D are on a four-scale metric, from rarely, to some days (1-2 days), to occasionally (3-4 days) to most of the time (5-7 days). We score these answers in the way suggested by the US National Institute of Mental Health researcher (Lenore Radloff) who created the CES-D, using numbers from 0 for rarely to 3 for most of the time, for negative questions such as do you feel sad. For positive questions do you feel happy, the scoring is reversed from 0 for most of the time to 3 for rarely.
} 
causality, which can run in both directions. However, Friedman and Thomas (2008) using a difference in difference approach with IFLS data find that the economic crisis fueled depression indicators in Indonesia, especially for the more vulnerable population.

Figure 6 displays a nonparametric regression between the CES-D score and age, for both men and women. As one can see, women have higher scores, indicating more depressive symptoms, but the male-female gap narrows at older ages.

Table 9 contains regression results for men and women where the outcome is the CES-D 10 score. Education dummies are jointly significant for women, but not for men. Having a junior high school level education is associated with a lower CES-D score by over 2.4-3 points for women, a considerable amount relative to one standard deviation, 0.38. PCE is also associated with lower CES-D scores for both men and women, and the impact is concave, being reduced at higher levels of pce. However, the impact of pce goes away when the community fixed effects are added. The community fixed effects are strongly significant. The SES results are quite similar to the Indonesia results from IFLS of Witoelar et al. (2009) and suggest that in Gansu and Zhejiang, depressive symptoms are strongly correlated with schooling and less so with income.

\section{Cognition-Word recall}

Cognition has been found to be an important issue among the elderly (see McArdle, Fisher and Kadlec, 2007). We use immediate and delayed word recall as our cognitive measure, namely the episodic memory measure. In CHARLS, like HRS, respondents are read a list of ten simple nouns and they are immediately asked to repeat as many as they can, in any order. After answering the 10 CES-D questions, plus some additional cognition questions on subtraction, maybe ten minutes later, respondents are then asked again to repeat as many words as they can. 
We use the average number of correctly immediate and delayed recalled words as our memory measure (see McArdle, Smith and Willis, 2009).

Figure 7 displays the mean number of words recalled by men and women, by age. Word recall declines in a concave manner with age, with a steeper decline at older ages. Some of this shape may also be caused by schooling being negatively correlated with age; regressions will thus be important to retrieve multivariate correlations. Men are better able to recall than women, which could be a function in part, of having more education. Indeed, in Table 10 the SES coefficients are positively correlated with word recall and strongly significant in almost all cases. Age dummies are significantly negatively correlated with word recall. Education at the junior high or above level for men is associated with 1.5 more words recalled, for women the marginal effect is quite similar. PCE is also highly correlated with word recall, although the direction of causality is much less clear. It is also the case for women that this correlation disappears when community fixed effects are added. The community dummies are jointly significant for both men and women. These results are consistent with the results of McArdle et al., 2009, for the HRS data where word recall is highly correlated with educational attainment.

\section{Survival expectations}

In CHARLS, as in the HRS, we ask respondents about the chances that they will live to a particular age. Respondents answer on a 5 point scale, from 1 which means almost no chance, to 5 which means virtual certainty. We do not ask probabilities directly since our pretest experience, and experience in other low-income countries indicated a real difficulty for respondents to understand probabilities. Experience with HRS and other aging surveys has shown that answers to this question are highly correlated with survival to subsequent waves (for example see Banks et al., 2009). 
The future age about which each respondent is asked depends on their current age, older respondents are asked about survival to older ages. That raises an issue that answers across respondents asked about different ages may not correspond well. Here we take respondents under age 65, all of whom were asked about survival to age 75, so that this issue does not arise. We construct our dependent variable to indicate whether the respondent thinks it is not very likely, or almost impossible, to reach age 75; the two lowest scores. Figure 8 displays the results by level of education. Overall, roughly $20 \%$ of men and women consider their chances to reach age 75 to be not very likely or nearly impossible. When we look by education, we see that for illiterate men and women $30 \%$ believe their chances of survival to age 75 are very unlikely or near impossible, but that declines to $10 \%$ of women and $20 \%$ of men with junior high education and above. Interestingly, women with low levels of schooling do not appear to understand that their (unconditional) older age mortality is lower than for men, although women with junior high school or more education apparently do.

Regression results are displayed in Table 11. For men, higher education is associated with a higher chance of survival, but the correlation is strongest for men with primary schooling, not junior high and above. PCE is positively related to survival expectations, but only until we add the regional dummies or community fixed effects, in which case the coefficient magnitudes drop towards zero and their significance disappears. For women, there are stronger education correlations than for men, which are mitigated when regional or community fixed effects are added. In those specifications, it is only having junior high school or greater schooling that matters. PCE also dissipates in its regression coefficient as regional or community fixed effects are added. Community dummies are jointly highly significant for both men and women.

\section{General health}


CHARLS followed the HRS example and asked respondents to assess their general health using two different scales: excellent, very good, good, fair, poor and very good, good, fair, poor, very poor. One was asked at the start of the health section, section CA, and one at the end of that section. Whether a respondent was asked one or the other first was determined randomly by CAPI. Here we use the excellent, very good, good, fair, poor scale. We look at whether respondents report poor health, as our variable of interest. About $19 \%$ of men and $27 \%$ of women report that they are in poor health. The fraction of respondents reporting fair health is quite high, $40 \%$. This is one reason why we do not combine fair and poor health as is done often in US studies. Apparently "fair" translates in Chinese to a word which is very commonly answered.

Figure 9 shows the bivariate relationship with education. As expected, better educated men and women report less being in poor health. The male-female differences narrow with the by education results because at each level of education, men are older than women.

Table 12 shows regression results for men and women. For men, education is not significantly related to reporting being in poor health, but pce is, negatively. The pce relation is non-linear, with pce making most if its difference at higher levels of pce. Note, once again, that when province-rural/urban dummies are added, or when community fixed effects are used, that the pce coefficients move towards zero and are not significant.

For women, the pce results are qualitatively similar to the male results. Education dummies are now significant, being negatively correlated with reporting being in poor health. However, when the province or community dummies are added only the junior high or above retains its significant correlation, and the coefficients collapse with both province-urban/rural dummies and community fixed effects significant. Respondents living in Gansu province are 
much more likely to report being in poor health. Some of this Gansu effect could represent different subjective scales being used in Gansu than in Zhejiang. But it is more than a Gansu effect, because when the community fixed effect specification is run by province, the community dummies are jointly significant within the Gansu regression. That means that there is considerable heterogeneity within Gansu but across communities in the propensity to report being in bad health.

\section{Smoking}

There is one health input that we examine in this paper, smoking. As in other Asian countries, smoking is a male issue (for evidence in China see Lance et al., 2004 and Kenkel et al., 2009, which find that cigarette demand is price inelastic). ${ }^{21} 22$ In Figure 10 we plot nonparametrically both the proportions who ever smoked and who are currently smoking, by age, for men. Overall, 52\% of men report currently smoking. There is a small downward trend in ever smoking by age, which must represent a birth cohort effect. However the vertical distance between ever and current smoking is growing by age, which indicates that there is quitting going on at older ages. It is also likely that a larger proportion of the smoking old have died than of the non-smoking old, which could cause this pattern.

Table 13 shows regression results for current and ever smoking for men. For ever smoking, we use only the age (birth cohort) and education dummies. Since factors apparent when the respondent was young are the ones that would be most correlated with ever smoking, we drop income variables and community or province dummies based on current residence. The

\footnotetext{
${ }^{21}$ Only $2 \%$ of women report that they currently smoke.

${ }^{22}$ Here smoking is defined as smoking cigarettes or cigars. Current smoking prevalence for older men in CHARLS is quite close to rates of 55\% reported from the China Health and Nutrition Survey (CHNS), for other provinces; see Kenkel et al. (2009). The CHNS rates are for all adult ages.
} 
education coefficients are positively correlated with ever smoking, but they are not significant at standard levels. Older cohorts are less likely to have ever smoked. This could also represent a mortality selection effect, as it may be that older smokers died prior to the CHARLS pilot survey. There is no relation between current smoking and education, but pce does have a positive one with higher income men are more likely to be smokers. At low levels of economic development, smoking and income are often positively correlated, but this reverses at high levels of development. The province-rural/urban dummies make no difference, but the community dummies do. Once again there is variation between communities and within province that is important.

\section{Conclusions}

This paper has presented estimates of the health-SES gradient in Gansu and Zhejiang provinces, China using multiple measures of health and of SES. China has undergone a significant health and nutrition transition such that under-nutrition is very much less of a problem for the elderly than it had been in the past and over-nutrition has become much more of an issue. In Zhejiang and Gansu provinces, where the CHARLS pilot was fielded, health conditions of the elderly, such as having difficulties with ADLs and IADLs, having depressive symptoms, word recall cognition and general health are all correlated with education, especially for women and to some degree for men as well; with better education being associated with better health outcomes. On the other hand, BMI is positively correlated with income and with education for men, while for women education has an inverted-U relationship with BMI. The latter may be consistent with the hypothesis that women are more likely than men to understand the relationships between BMI and future health problems, but this will require more research. The correlations 
of health measures with income, as measured by percapita expenditure, are more mixed. On the one hand, pce is positively correlated with some health measures, such as BMI, IADLs, word recall and self-reported general health, but many times that correlation shrinks and becomes insignificant when community dummies at the primary sampling unit (PSU) level are entered into the regressions.

One of the most important findings in this analysis is the apparent importance of regional and community factors. What exactly lies behind this is not yet clear and needs to be the subject of future research. From economic theory there are a number of factors that should be part of the story. Prices of health inputs is surely one such factor, as should be the availability and quality of health care services. Public health infrastructure should be another such factor, as should the inherent healthiness of a community due to factors like water, sanitation and air quality. Different and changing food or diet preferences are also no doubt related to these findings. Given the strength of the relationships, however, it may well be that there are other community influences that are important, perhaps including factors that related to social interaction and stress, that are particularly important in Gansu and Zhejiang. However at this point, all of these hypotheses represent speculation.

The other important finding in this research is the large-scale under-diagnosis of hypertension, which is correlated positively with education, at least for women and with community location for both men and women. This represents a major health system gap and one which is probably more serious for other, less prevalent, chronic conditions of the elderly. This problem is certainly not unique to Gansu and Zhejiang and seems to exist in other countries that are still in the midst of the health transition from infectious to chronic diseases. Health systems in such health transition countries apparently take time to re-orient their systems to 
diagnose and treat chronic diseases of the aging and aged. This is an important step that the health systems in Gansu and Zhejiang will need to work out in the future. 


\section{References}

Banks, James, Michael Marmot, Zoe Oldfield, and James P. Smith. 2006. "Disease and Disadvantage in the United States and in England," Journal of the American Medical Association, 295(17):2037-2045.

Banks, James, Alastair Muriel and James P. Smith, 2009. "Disease prevalence, incidence and determinants of mortality in the United States and England", manuscript, Department of Economics, University College London.

Barker, David, 1994. Mothers, babies and health in later life, London: BMJ Publishing Group.

Barker, David. 1997. "Maternal Nutrition, Fetal Nutrition and Diseases in Later Life," Nutrition 13(9): 807-813.

Börch-Supan, Axel, Agar Brugiavini, Hendrik Jürges, Arie Kapteyn, Johan Mackenbach, Johannes Siegrist, Guglielmo Webger, 2008. First Results from the Survey of Health, Ageing and Retirement in Europe (2004-2007). Mannheim Research Institute for the Economics of the Aging (MEA).

Cutler, David and Adriana Lleras-Muney. 2010. "Understanding Differences in Health Behaviors by Education”, Journal of Health Economics, forthcoming.

Das, Jishnu, Quy-Toan, Do, Jed Friedman, David McKenzie, and Kinnon Scott, 2007. “Mental health and poverty in developing countries", Social Science and Medicine, 65(3):467480 .

Friedman, Jed and Duncan Thomas, 2008. "Psychological health, before, during and after an economic crisis: Results from Indonesia 1993-2000”, World Bank Economic Review, 23(1):57-76.

Goldman, Dana and James P. Smith. "Can Patient Self-Management Help Explain the SES Health Gradient?” Proceedings of the National Academy of Sciences 99(16):1092910934, August 6, 2002

Gluckman, Peter and Mark Hanson, 2005. The fetal matrix: Evolution, development and disease, Cambridge.

Hoddinott, John; John Maluccio, Jere Behrman, R. Flores and Reynaldo Martorell. 2008. "Effect of a Nutrition Intervention During Early Childhood on Economic Productivity in Guatemalan Adults”, Lancet, 371:411-416

Hossain, Shaikh. 1997. "Tackling health transition in China”, Policy Research Working Paper No. 1813, Washington D.C.: World Bank. 
Kenkel, Don, Dean Lillard and Feng Liu. 2009. “An analysis of life-course smoking behavior in China”, Health Economics, 18:S147-S156.

Kinsella, Kevin and Wan He, 2009. An aging world: 2008, US Census Bureau, International Population Reports, PS95/09-1, Washington D.C.: US Government Printing Office.

Lance, Peter, John Akin, William Dow and C Loh. 2004. "Is cigarette smoking in poorer nations sensitive to price?: Evidence from Russia and China”, Journal of Health Economics, 23:173-189.

Lee, Nayoung. 2009. "Measurement error and its impact on estimates of income and consumption dynamics”, mimeo, Department of Economics, Chinese University of Hong Kong.

Lee, Jinkook and James P. Smith . 2008. "Explanations for Education Gradients in DepressionThe Case of Korea,” mimeo, RAND Corporation, Santa Monica, CA.

Lleras-Muney, Adriana. 2005. “The Relationship Between Education and Adult Mortality in the US”, Review of Economic Studies, 72(1):189-221.

Lopez, Alan, Colin Mathers, Majid Ezzati, Dean Jamison and Christopher Murray. 2006. "Measuring the global burden of disease and risk factors, 1990-2001”, in A. Lopez, C. Mathers, M. Ezzati, D. Jamison, and C. Murray (eds.), Global Burden of Disease and Risk Factors, Oxford: Oxford University Press.

Luo, Zhehui. 2003. "Socioeconomic determinants of body mass index of adults Chinese in 1990s”, presented at the Northeast Consortium Development Conference (NEUDC), October 2003. mimeo, Department of Epidemiology, Michigan State University.

Maluccio, John; John Hoddinott; Jere Behrman; Reynaldo Martorell; Agnes Quisumbing and Aryeh Stein. 2009. "The Impact of Improving Nutrition During Early Childhood on Education Among Guatemalan Adults”, Economic Journal, 119(537):734-763.

Marmot, Michael.G. 1999. "Multi-level Approaches to Understanding Social Determinants,” in L. Berkman and I. Kawachi (eds.), Social Epidemiology, Oxford: Oxford University Press, pp. 349-367.

McArdle, John, Gwenith Fisher and Kelly Kadlec, 2007. "Latent variable analysis of age trends in tests of cognitive ability in the Health and Retirement Survey, 1992-2004”, Psychology and Aging, 22(3):525-545.

McArdle, John, James P. Smith and Robert Willis, 2009. “Cognition and economic outcomes in the Health and Retirement Survey”, manuscript, RAND Corporation, Santa Monica, CA.

Patel, V. and A. Kleinman, 2003. "Poverty and common mental disorders in developing countries”, Bulletin of the World Health Organization, 81(8):609-615. 
Popkin, Barry, Keyou Ge, Fengying Zhai, X Guo, H Ma and N Zohoori. 1993. "The nutrition transition in China: A cross-sectional analysis”, European Journal of Clinical Nutrition, 47:333-346.

Popkin, Barry, 1994. "The nutrition transition in low-income countries: An emerging crisis”, Nutrition Reviews, 52(9):285-298.

Popkin, Barry, Sahasporn Paeratakul, Fengying Zhai and Keyou Ge. 1995a. “A review of dietary and environmental correlates of obesity with emphasis on developing countries", Obesity Research, 3(S2):S145-S153.

Popkin, Barry, Sahasporn Paeratakul, Fengying Zhai and Keyou Ge. 1995b. "Dietary and environmental correlates of obesity in a population study of China”, Obesity Research, 3(S2):S135-S143.

Popkin, Barry. 1999. “Urbanization, lifestyle changes and the nutrition transition”, World Development, 27(11):1905-1916.

Popkin, Barry. 2002. "The shift in stages of the nutrition transition in the developing world differs from past experiences”, Public Health Nutrition, 5(1A):205-214.

Seeman, Theresa, Burt Singer, J. Rowe, R. Horwitz, and B. McEwen. 1997. "Price of AdaptionAllostatic Load and Its Health Consequences,” Archives of Internal Medicine, 157(19): 2259-2268.

Smith, James P. 1999. "Healthy bodies and thick wallets: The dual relation between health and economic status”, Journal of Economic Perspectives, 13(2):145-167.

Smith, James P. 2009 "The Impact of Childhood Health on Adult Labor Market Outcomes,” Review of Economics and Statistics 91(3):478-489.

Schultz, T. Paul. 1984. "Studying the impact of household economic and community variables on child mortality”, in W.H. Mosely, and L. Chen (eds.), Child Survival: Strategies for Research, Population and Development Review, 10(Supplement):215-236.

Strauss, John. 1986. “Does Better Nutrition Raise Farm Productivity? Journal of Political Economy, 94(2):297-320.

Strauss, John. 1993. "The Impact of Improved Nutrition on Labor Productivity and Human Resource Development: An Economic Perspective”, in P. Pinstrup-Andersen (ed.), The Political Economy of Food and Nutrition Policies, Baltimore: Johns Hopkins Press.

Strauss, John and Duncan Thomas, 1995. "Human resources: empirical modeling of household and family decisions”, in J.R. Behrman and T.N. Srinivasan (eds.), Handbook of Development Economics, Volume 3A, Amsterdam: North Holland Press. 
Strauss, John and Duncan Thomas. 1998. "Health, nutrition and economic development”, Journal of Economic Literature, 36(3):766-817.

Strauss, John and Duncan Thomas. 2008. "Health over the life course”, in T.P. Schultz and J. Strauss (eds.), Handbook of Development Economics, Volume 4, Amsterdam: North Holland Press.

Thomas, Duncan. 2010. "Health and Socio-economic Status: The Importance of Causal Pathways”, in Justin Yifu Lin and Boris Pleskovic (eds.), Annual World Bank Conference on Development Economics, Global 2009, Washington D.C., World Bank, pp.355-384.

Thomas, Duncan and John Strauss. 1997. "Health and Wages: Evidence for Men and Women in Urban Brazil”, Journal of Econometrics, 77(1):159-186.

Thomas, Duncan, John Strauss and Maria-Helena Henriques. 1991. "How does mother's education affect child height?”, Journal of Human Resources, 26(2):183-211.

UNICEF. 2009. China Statistics, www.unicef.org/infobycountry/china_statistics.html.

Wagstaff, Adam, Winnie Yip, Magnus Lindelow and William Hsiao. 2009. “China’s health system and its reform: A review of recent studies”, 18:S7-S23.

Waaler, Hans. 1984. "Height, weight and mortality: The Norwegian experience”, Acta Medica Scaninavica, 215(S679):1-56.

Wilkenson, R.G. (1996). Unhealthy Societies: The Afflictions of Inequality, London: Routledge.

Witoelar, Firman, John Strauss and Bondan Sikoki 2009. "Socioeconomic success and health in later life: Evidence from the Indonesia Family Life Survey”. mimeo, University of Southern California.

World Bank. 2009. From Poor Areas to Poor People: China's Evolving Poverty Reduction Agenda, Washington D.C.: World Bank.

World Health Organization. 2009. China, WHO Country Health Information Profiles.

Zhao, Yaohui, John Strauss, Albert Park and Yan Sun. 2009. "China Health and Retirement Longitudinal Study User’s Guide”, China Center for Economic Research, Peking University. 


\section{Figure 1}

Relationship Between BMI and Education in Selected Countries

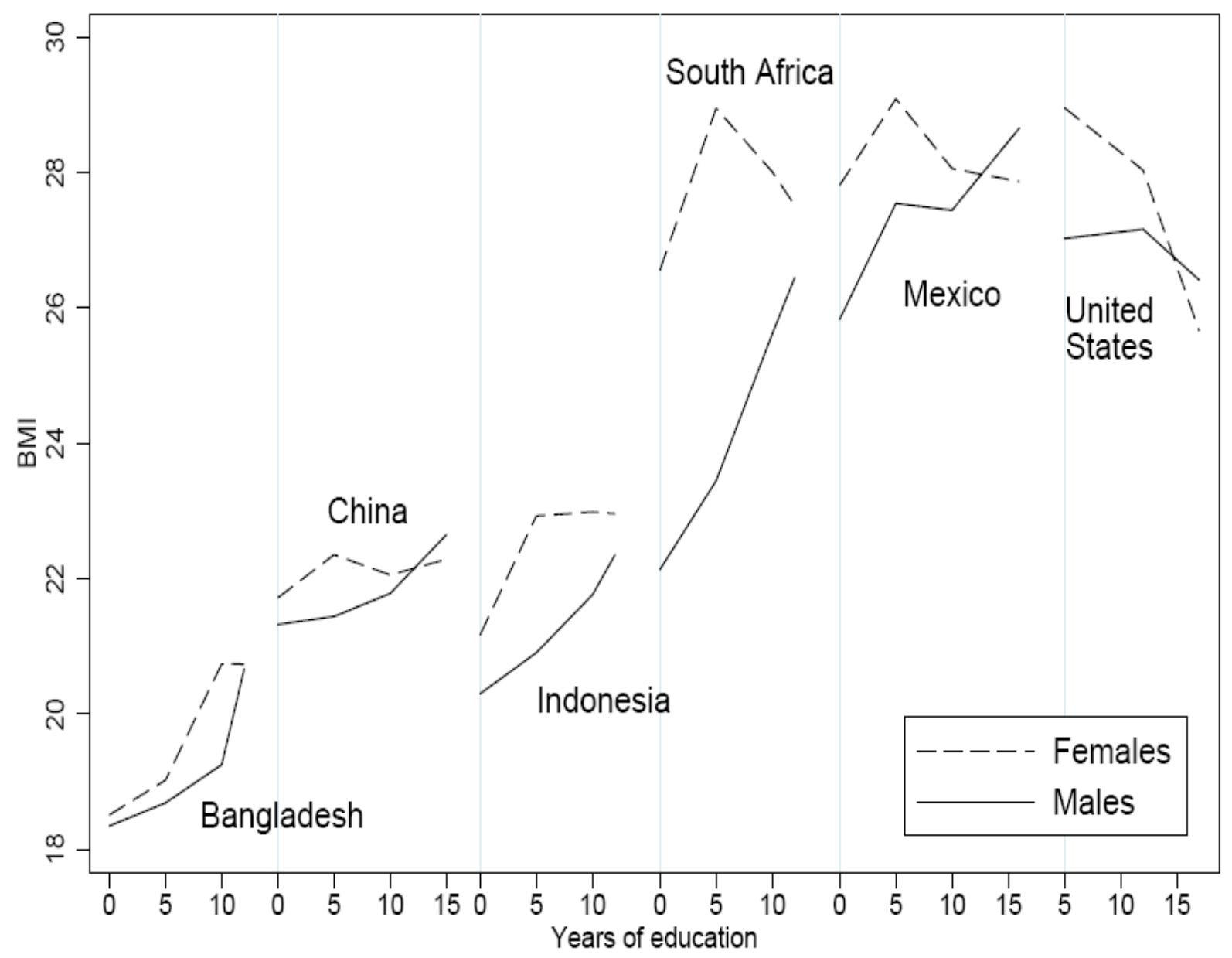

Reproduced from Strauss and Thomas (2008). 
Figure 2. BMI, by Sex and Education

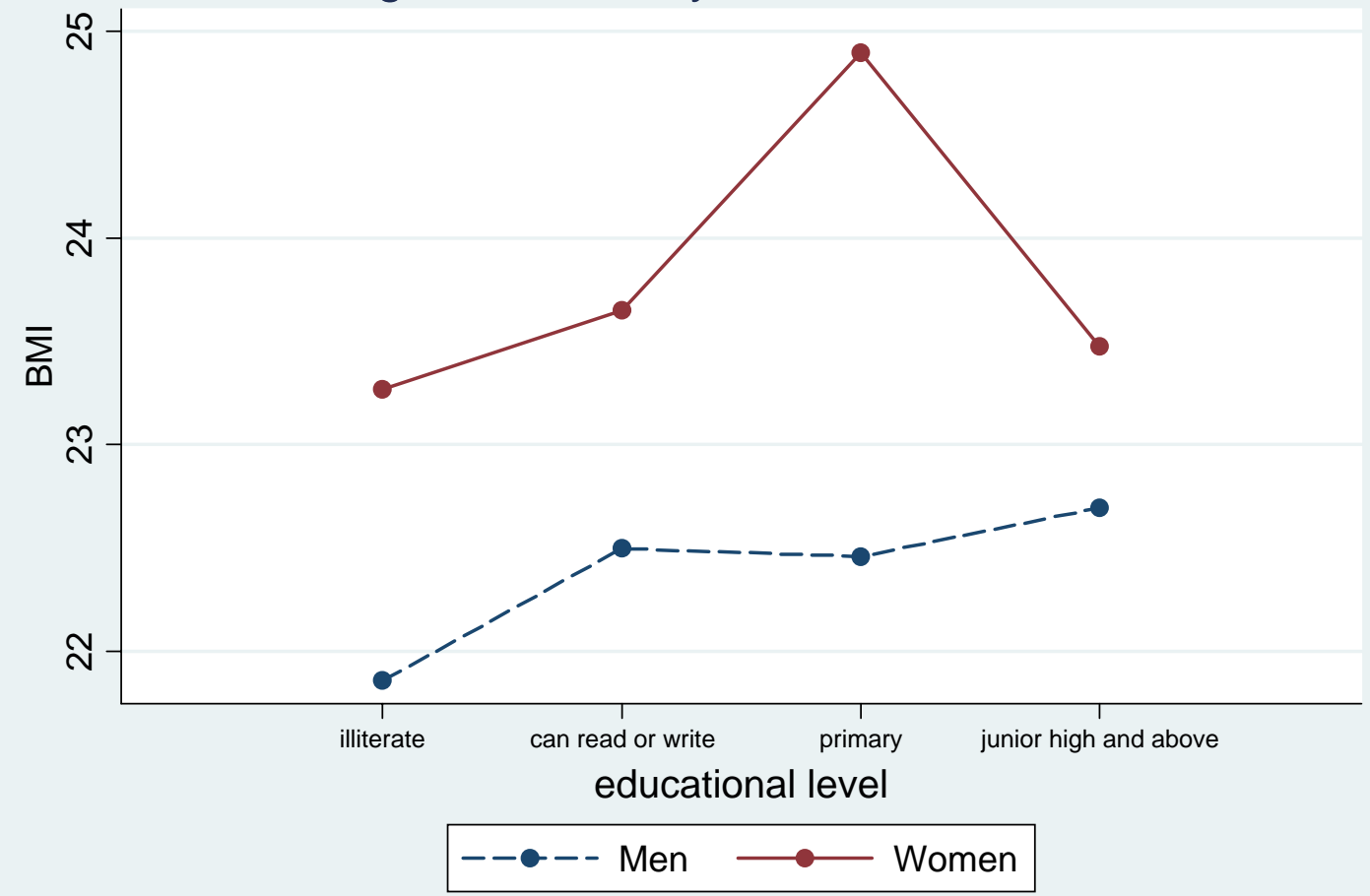


Figure 3. Hypertension and Age

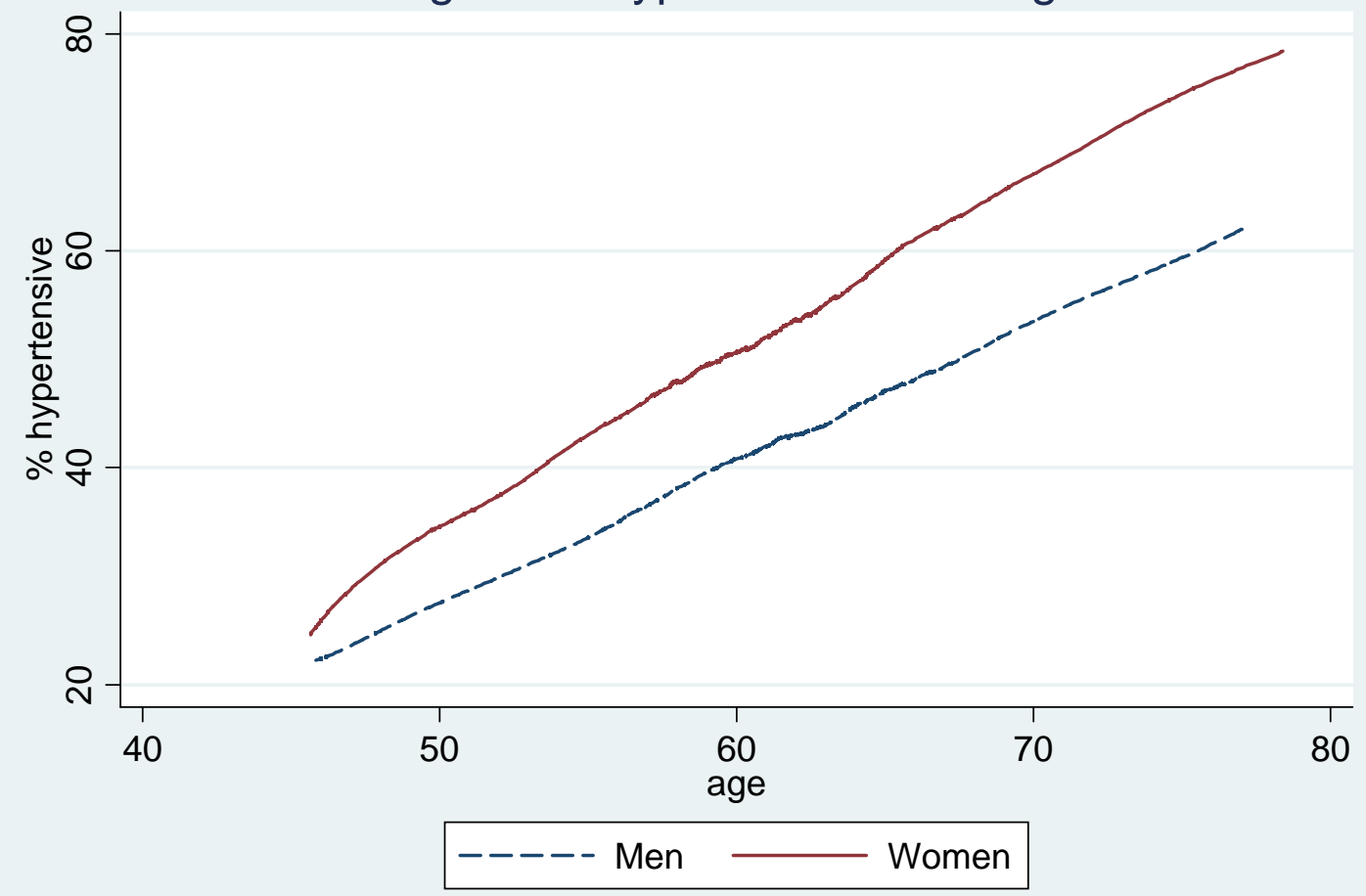


Figure 4. Numbers of Difficulties with ADL, by sex and educational level

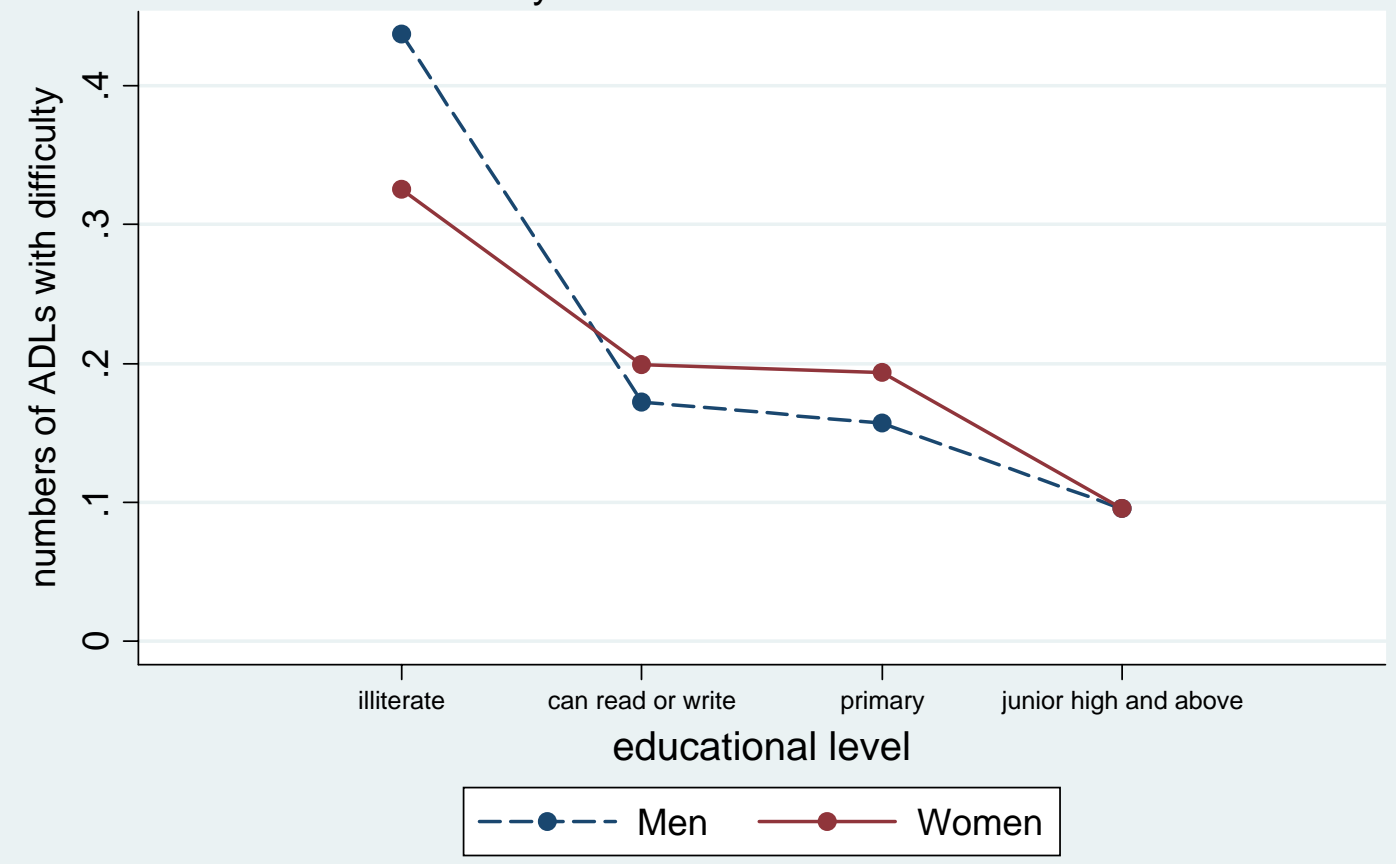


Figure 5. Numbers of Difficulties with IADL, by sex and educational level

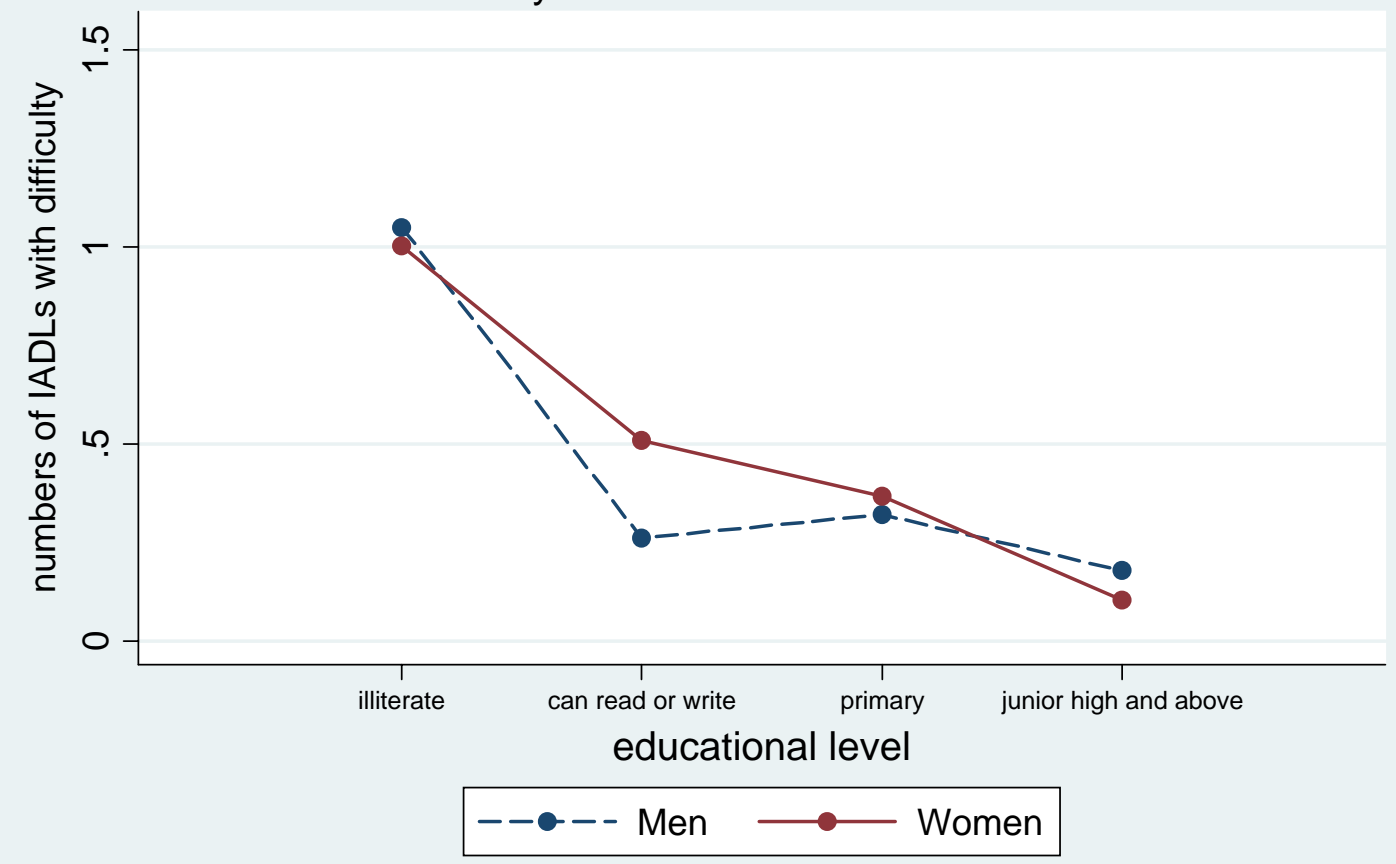


Figure 6. CES-D 10 against Age

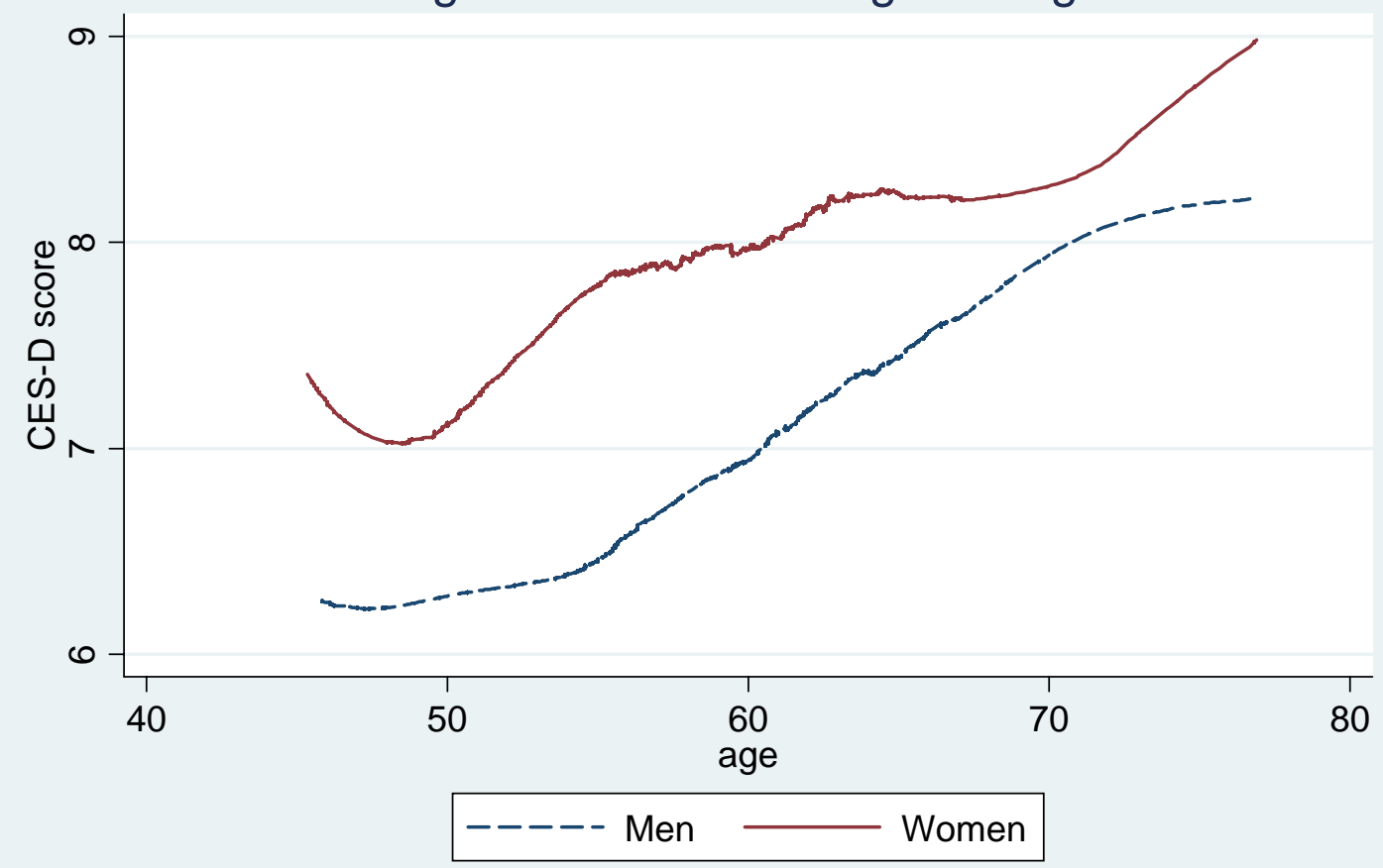

Center for Epidemiologic Studies-Depression scale 
Figure 7. Number of Words Recalled against Age

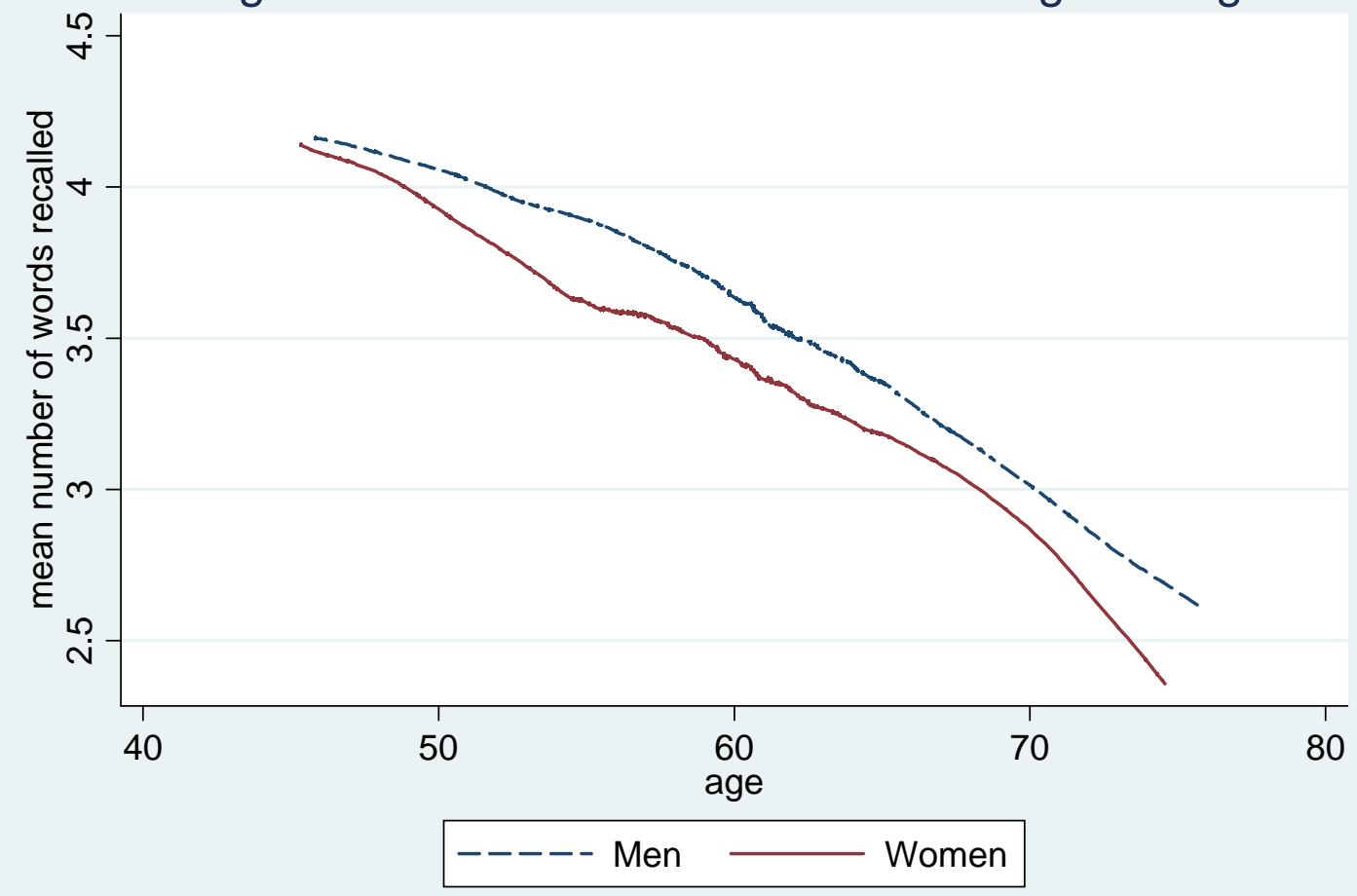


Figure 8. Life Expectation to 75,

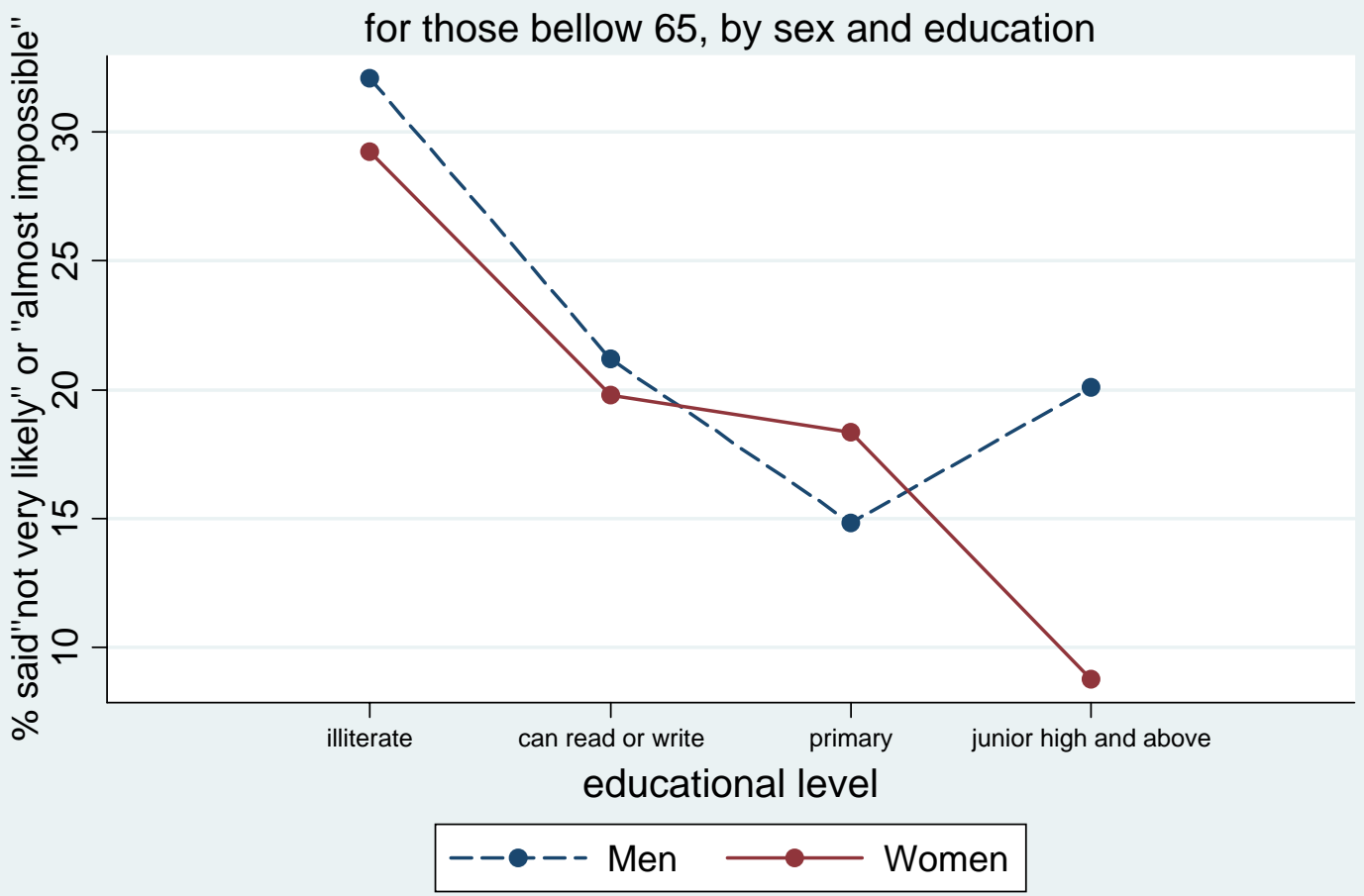


Figure 9. Self-reported General Health, by sex and educational level

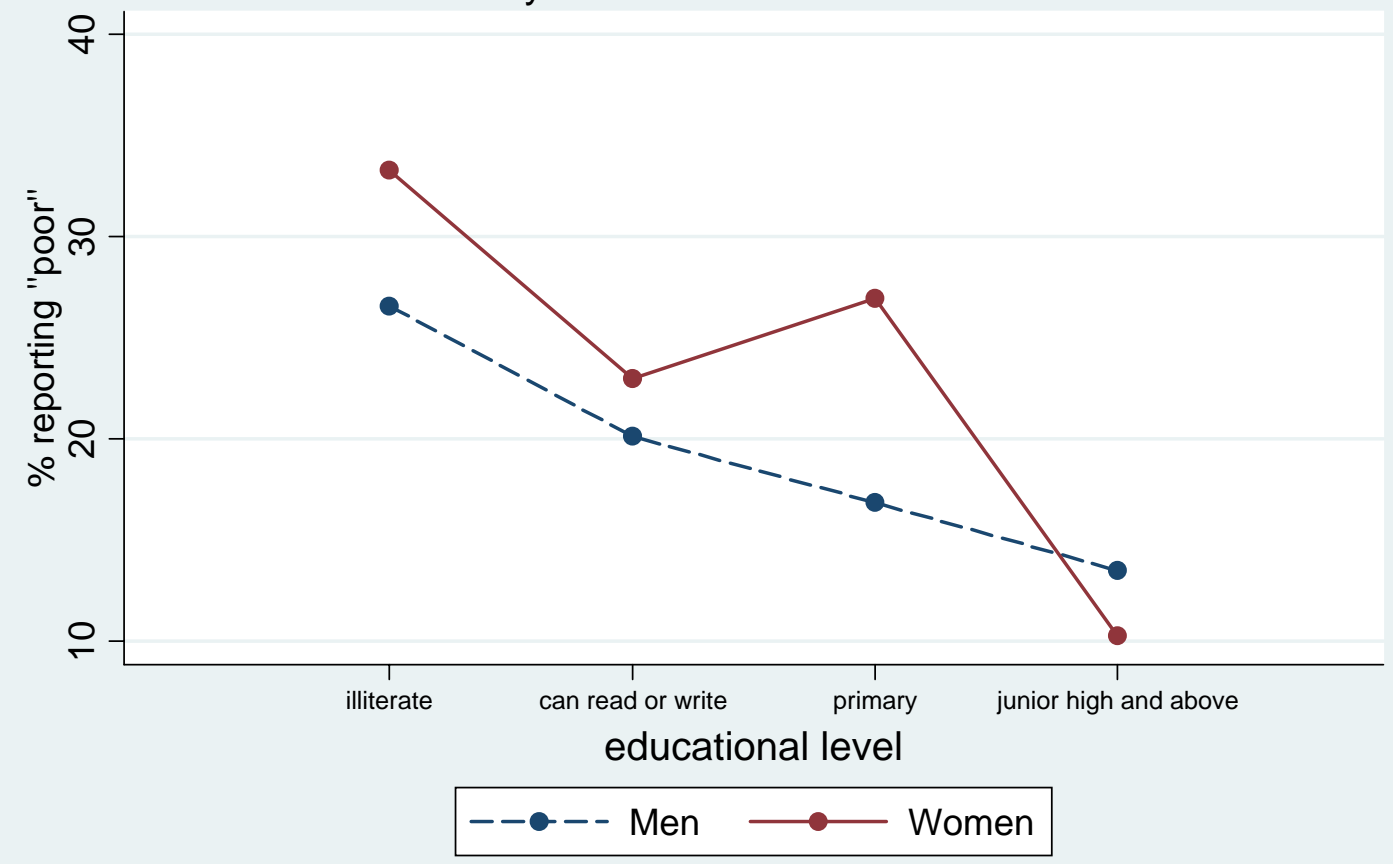


Figure 10. Male Smoking by Age

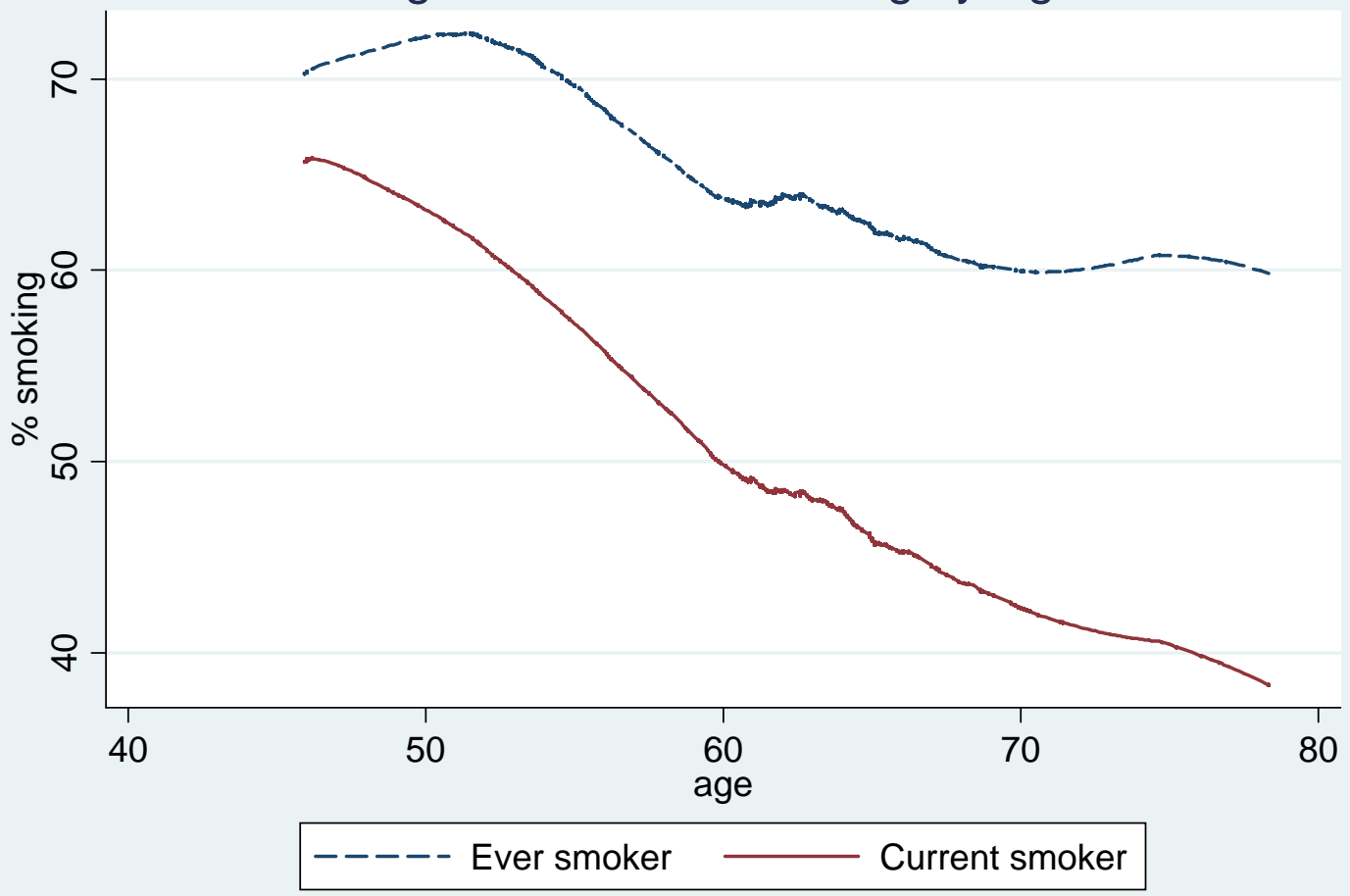


Table 1. Means and Standard Deviations of Regression Variables

\begin{tabular}{|c|c|c|c|c|}
\hline & \multicolumn{2}{|c|}{ Men } & \multicolumn{2}{|c|}{ Women } \\
\hline & Mean & SD & Mean & SD \\
\hline BMI & 22.3 & 0.15 & 23.6 & 0.15 \\
\hline CES-D 10 & 7.5 & 0.26 & 8.7 & 0.38 \\
\hline Number of words recalled & 3.6 & 0.07 & 3.3 & 0.09 \\
\hline $\begin{array}{c}\text { "Not very likely" or "almost impossible" to } \\
\text { reach } 75\end{array}$ & 0.25 & 0.026 & 0.26 & 0.026 \\
\hline Hypertension & 0.38 & 0.018 & 0.49 & 0.019 \\
\hline Under-diagnosis of hypertension & 0.49 & 0.028 & 0.42 & 0.026 \\
\hline Poor general health & 0.22 & 0.016 & 0.30 & 0.020 \\
\hline Number of difficulties in ADLs & 0.23 & 0.027 & 0.29 & 0.031 \\
\hline Number of difficulties in IADLs & 0.48 & 0.046 & 0.84 & 0.082 \\
\hline Age & 60.4 & 0.34 & 59.5 & 0.35 \\
\hline Aged 45-54 & 0.35 & 0.015 & 0.40 & 0.015 \\
\hline Aged 55-64 & 0.33 & 0.015 & 0.33 & 0.014 \\
\hline Aged 65-74 & 0.22 & 0.014 & 0.18 & 0.011 \\
\hline Aged 75+ & 0.09 & 0.009 & 0.09 & 0.009 \\
\hline Illiterate & 0.26 & 0.016 & 0.62 & 0.027 \\
\hline Can read or write & 0.23 & 0.015 & 0.14 & 0.013 \\
\hline Finished primary & 0.23 & 0.013 & 0.11 & 0.012 \\
\hline Junior high or above & 0.28 & 0.019 & 0.13 & 0.015 \\
\hline Log PCE & 8.4 & 0.06 & 8.4 & 0.06 \\
\hline Rural Gansu & 0.33 & 0.051 & 0.30 & 0.049 \\
\hline Urban Gansu & 0.14 & 0.035 & 0.17 & 0.039 \\
\hline Rural Zhejiang & 0.25 & 0.048 & 0.24 & 0.047 \\
\hline Urban Zhejiang & 0.28 & 0.049 & 0.29 & 0.051 \\
\hline
\end{tabular}

Note: the means are unweighted and the standard deviations are clustered at the community level. 
Table 2. BMI, by age and sex

\begin{tabular}{|c|c|c|c|c|c|c|c|c|}
\hline & \multicolumn{4}{|c|}{ Men } & \multicolumn{4}{|c|}{ Women } \\
\hline & $\begin{array}{l}\text { BMI } \\
\text { Mean }\end{array}$ & $\begin{array}{c}\% \text { BMI } \\
<18.5\end{array}$ & $\begin{array}{l}\% \text { BMI } \\
>=25.0\end{array}$ & $N$ & $\begin{array}{l}\text { BMI } \\
\text { Mean }\end{array}$ & $\begin{array}{c}\% \text { BMI } \\
<18.5\end{array}$ & $\begin{array}{l}\% \text { BMI } \\
>=25.0\end{array}$ & $N$ \\
\hline $45-54$ & $\begin{array}{l}22.8 \\
(0.2)\end{array}$ & $\begin{array}{c}5.4 \\
(1.7)\end{array}$ & $\begin{array}{l}26.4 \\
(3.7)\end{array}$ & 334 & $\begin{array}{l}23.7 \\
(0.2)\end{array}$ & $\begin{array}{c}4.7 \\
(1.3)\end{array}$ & $\begin{array}{c}35.3 \\
(2.9)\end{array}$ & 371 \\
\hline 55-64 & $\begin{array}{l}22.8 \\
(0.2)\end{array}$ & $\begin{array}{c}3.4 \\
(1.2)\end{array}$ & $\begin{array}{l}23.9 \\
(3.0)\end{array}$ & 317 & $\begin{array}{l}23.9 \\
(0.2)\end{array}$ & $\begin{array}{c}5.0 \\
(1.3)\end{array}$ & $\begin{array}{l}39.2 \\
(3.2)\end{array}$ & 305 \\
\hline $65-74$ & $\begin{array}{l}21.5 \\
(0.3)\end{array}$ & $\begin{array}{c}9.3 \\
(2.3)\end{array}$ & $\begin{array}{l}14.4 \\
(3.3)\end{array}$ & 203 & $\begin{array}{l}23.3 \\
(0.3)\end{array}$ & $\begin{array}{l}10.7 \\
(2.6)\end{array}$ & $\begin{array}{l}29.2 \\
(4.0)\end{array}$ & 169 \\
\hline $75+$ & $\begin{array}{l}21.2 \\
(0.4)\end{array}$ & $\begin{array}{l}17.2 \\
(5.1)\end{array}$ & $\begin{array}{l}10.3 \\
(3.7)\end{array}$ & 66 & $\begin{array}{l}21.8 \\
(0.5)\end{array}$ & $\begin{array}{l}21.6 \\
(6.1)\end{array}$ & $\begin{array}{l}12.8 \\
(4.3)\end{array}$ & 74 \\
\hline $\begin{array}{l}\text { Total } \\
(45+)\end{array}$ & $\begin{array}{l}22.4 \\
(0.2)\end{array}$ & $\begin{array}{c}6.5 \\
(1.0)\end{array}$ & $\begin{array}{l}21.7 \\
(2.2)\end{array}$ & 920 & $\begin{array}{l}23.6 \\
(0.1)\end{array}$ & $\begin{array}{c}7.3 \\
(0.9)\end{array}$ & $\begin{array}{l}33.6 \\
(1.9)\end{array}$ & 919 \\
\hline
\end{tabular}

Standard errors in parentheses. 
Table 3. Regressions for BMI

\begin{tabular}{|c|c|c|c|c|c|c|}
\hline & \multicolumn{3}{|c|}{ Men } & \multicolumn{3}{|c|}{ Women } \\
\hline & $(1)$ & $(2)$ & $(3)$ & $(1)$ & $(2)$ & (3) \\
\hline \multirow[t]{2}{*}{ Aged 55-64 } & 0.163 & 0.147 & 0.102 & -0.076 & -0.089 & -0.257 \\
\hline & $(0.215)$ & $(0.207)$ & $(0.216)$ & $(0.281)$ & $(0.272)$ & $(0.308)$ \\
\hline \multirow[t]{2}{*}{ Aged 65-74 } & $-0.760 * * *$ & $-0.885^{* * *}$ & $-1.073 * * *$ & -0.374 & -0.468 & -0.597 \\
\hline & $(0.281)$ & $(0.279)$ & $(0.317)$ & $(0.363)$ & $(0.357)$ & $(0.405)$ \\
\hline \multirow[t]{2}{*}{ Aged 75 and over } & $-0.827^{*}$ & $-0.909 *$ & $-1.190 * *$ & $-1.733^{* * *}$ & $-1.790 * * *$ & $-2.004 * * *$ \\
\hline & $(0.486)$ & $(0.480)$ & $(0.507)$ & $(0.501)$ & $(0.499)$ & $(0.610)$ \\
\hline \multirow[t]{2}{*}{ Can read and write } & 0.294 & 0.236 & 0.294 & 0.340 & 0.324 & 0.012 \\
\hline & $(0.272)$ & $(0.274)$ & $(0.318)$ & $(0.292)$ & $(0.301)$ & $(0.316)$ \\
\hline \multirow[t]{2}{*}{ Finished primary } & 0.240 & 0.159 & 0.236 & $1.251 * * *$ & $1.159 * *$ & $0.956 * *$ \\
\hline & $(0.278)$ & $(0.267)$ & $(0.306)$ & $(0.442)$ & $(0.450)$ & $(0.452)$ \\
\hline \multirow[t]{2}{*}{ Junior high and above } & 0.427 & 0.236 & -0.024 & 0.130 & -0.147 & -0.561 \\
\hline & $(0.273)$ & $(0.270)$ & $(0.308)$ & $(0.392)$ & $(0.375)$ & $(0.416)$ \\
\hline \multirow[t]{2}{*}{ Log pce $(<$ median $)$} & $0.491^{* * * *}$ & $0.410 * * *$ & $0.267 * *$ & 0.150 & 0.145 & 0.061 \\
\hline & $(0.115)$ & $(0.122)$ & $(0.122)$ & $(0.120)$ & $(0.121)$ & $(0.120)$ \\
\hline \multirow{2}{*}{$\begin{array}{l}\text { log pce (> median, } \\
\text { marginal) }\end{array}$} & 0.214 & 0.143 & 0.052 & 0.232 & 0.254 & 0.313 \\
\hline & $(0.293)$ & $(0.283)$ & $(0.326)$ & $(0.333)$ & $(0.332)$ & $(0.346)$ \\
\hline \multirow[t]{2}{*}{ Rural Zhejiang } & & -0.139 & & & 0.187 & \\
\hline & & $(0.299)$ & & & $(0.336)$ & \\
\hline \multirow[t]{2}{*}{ Urban Gansu } & & $1.034 * * *$ & & & $1.144^{* *}$ & \\
\hline & & $(0.350)$ & & & $(0.438)$ & \\
\hline \multirow[t]{2}{*}{ Rural Gansu } & & -0.603 & & & -0.090 & \\
\hline & & $(0.395)$ & & & $(0.428)$ & \\
\hline Community FE & NO & NO & YES & NO & NO & YES \\
\hline $\begin{array}{l}\text { F-test for all age } \\
\text { dummies }\end{array}$ & $3.94 * *$ & $5.33^{* * *}$ & $6.45^{* * *}$ & $4.41^{* * *}$ & $4.91^{* * *}$ & $3.85 * *$ \\
\hline (p-value) & $(0.011)$ & $(0.002)$ & $(0.001)$ & $(0.006)$ & $(0.003)$ & $(0.012)$ \\
\hline $\begin{array}{l}\text { F-test for all education } \\
\text { dummies }\end{array}$ & 0.83 & 0.33 & 0.59 & $2.66^{*}$ & $2.35 *$ & $2.42 *$ \\
\hline (p-value) & $(0.479)$ & $(0.801)$ & $(0.622)$ & $(0.053)$ & $(0.077)$ & $(0.071)$ \\
\hline $\begin{array}{l}\text { F-test for all log pce } \\
\text { splines }\end{array}$ & $22.79 * * *$ & $11.68 * * *$ & $3.94 * *$ & $2.43 *$ & $2.49 *$ & 1.11 \\
\hline (p-value) & $(0.000)$ & $(0.000)$ & $(0.023)$ & $(0.094)$ & $(0.089)$ & $(0.333)$ \\
\hline $\begin{array}{l}\text { F-test for all location } \\
\text { dummies }\end{array}$ & & $6.33^{* * *}$ & $3.85^{* * *}$ & & $2.89 * *$ & $2.14^{* * *}$ \\
\hline (p-value) & & $(0.001)$ & $(0.000)$ & & $(0.040)$ & $(0.000)$ \\
\hline Observations & 917 & 917 & 917 & 918 & 918 & 918 \\
\hline
\end{tabular}

Robust standard errors in parentheses, all clustered at community level.

$* \mathrm{p}<.1 * * \mathrm{p}<.05 * * * \mathrm{p}<.01$.

$\log (>$ median, marginal) represents the change in the slope from the interval for log pce below the median, see footnote 9 . 
Table 4. Regressions for hypertension

\begin{tabular}{|c|c|c|c|c|c|c|}
\hline & \multicolumn{3}{|c|}{ All Men } & \multicolumn{3}{|c|}{ All Women } \\
\hline & $(1)$ & $(2)$ & $(3)$ & $(1)$ & $(2)$ & $(3)$ \\
\hline Aged 55-64 & $\begin{array}{l}0.089 * * \\
(0.035)\end{array}$ & $\begin{array}{l}0.089 * * \\
(0.036)\end{array}$ & $\begin{array}{l}0.096 * * \\
(0.039)\end{array}$ & $\begin{array}{l}0.151^{* * *} \\
(0.040)\end{array}$ & $\begin{array}{c}0.150 * * * \\
(0.040)\end{array}$ & $\begin{array}{c}0.141^{* * *} \\
(0.044)\end{array}$ \\
\hline Aged 65-74 & $\begin{array}{c}0.260 * * * \\
(0.046)\end{array}$ & $\begin{array}{c}0.257 * * * \\
(0.047)\end{array}$ & $\begin{array}{c}0.251^{* * *} \\
(0.050)\end{array}$ & $\begin{array}{c}0.322 * * * \\
(0.039)\end{array}$ & $\begin{array}{c}0.317 * * * \\
(0.040)\end{array}$ & $\begin{array}{c}0.309 * * * \\
(0.045)\end{array}$ \\
\hline Aged 75 and over & $\begin{array}{c}0.355^{* * *} \\
(0.055)\end{array}$ & $\begin{array}{c}0.355^{* * *} \\
(0.055)\end{array}$ & $\begin{array}{c}0.347 * * * \\
(0.065)\end{array}$ & $\begin{array}{c}0.416^{* * *} \\
(0.050)\end{array}$ & $\begin{array}{c}0.415^{* * *} \\
(0.052)\end{array}$ & $\begin{array}{c}0.410^{* * *} \\
(0.062)\end{array}$ \\
\hline Can read and write & $\begin{array}{c}0.021 \\
(0.051)\end{array}$ & $\begin{array}{c}0.022 \\
(0.051)\end{array}$ & $\begin{array}{l}-0.001 \\
(0.057)\end{array}$ & $\begin{array}{c}0.028 \\
(0.044)\end{array}$ & $\begin{array}{c}0.029 \\
(0.047)\end{array}$ & $\begin{array}{c}0.054 \\
(0.050)\end{array}$ \\
\hline Finished primary & $\begin{array}{c}0.005 \\
(0.049)\end{array}$ & $\begin{array}{c}0.003 \\
(0.048)\end{array}$ & $\begin{array}{l}-0.013 \\
(0.054)\end{array}$ & $\begin{array}{c}0.009 \\
(0.050)\end{array}$ & $\begin{array}{c}0.007 \\
(0.051)\end{array}$ & $\begin{array}{c}0.023 \\
(0.064)\end{array}$ \\
\hline Junior high and above & $\begin{array}{c}0.043 \\
(0.043)\end{array}$ & $\begin{array}{c}0.036 \\
(0.045)\end{array}$ & $\begin{array}{c}0.018 \\
(0.050)\end{array}$ & $\begin{array}{l}-0.053 \\
(0.057)\end{array}$ & $\begin{array}{l}-0.062 \\
(0.056)\end{array}$ & $\begin{array}{c}-0.071 \\
(0.060)\end{array}$ \\
\hline Log pce (< median) & $\begin{array}{l}-0.018 \\
(0.035)\end{array}$ & $\begin{array}{l}-0.018 \\
(0.035)\end{array}$ & $\begin{array}{l}-0.015 \\
(0.029)\end{array}$ & $\begin{array}{l}-0.003 \\
(0.018)\end{array}$ & $\begin{array}{l}-0.003 \\
(0.018)\end{array}$ & $\begin{array}{l}-0.001 \\
(0.022)\end{array}$ \\
\hline $\begin{array}{l}\log \text { pce }(>\text { median, } \\
\text { marginal) }\end{array}$ & 0.059 & 0.059 & 0.047 & 0.047 & 0.050 & 0.051 \\
\hline & $(0.063)$ & $(0.063)$ & $(0.059)$ & $(0.046)$ & $(0.046)$ & $(0.054)$ \\
\hline Rural Zhejiang & & $\begin{array}{l}-0.003 \\
(0.046)\end{array}$ & & & $\begin{array}{c}0.028 \\
(0.046)\end{array}$ & \\
\hline Urban Gansu & & $\begin{array}{c}0.043 \\
(0.067)\end{array}$ & & & $\begin{array}{c}0.057 \\
(0.055)\end{array}$ & \\
\hline Rural Gansu & & $\begin{array}{l}-0.002 \\
(0.046)\end{array}$ & & & $\begin{array}{c}0.009 \\
(0.050)\end{array}$ & \\
\hline Community FE & NO & NO & YES & NO & NO & YES \\
\hline $\begin{array}{l}\text { F-test for all age } \\
\text { dummies } \\
\text { (p-value) }\end{array}$ & $\begin{array}{c}18.10^{* * *} \\
(0.000)\end{array}$ & $\begin{array}{c}18.17^{* * *} \\
(0.000)\end{array}$ & $\begin{array}{c}13.39 * * * \\
(0.000)\end{array}$ & $\begin{array}{c}34.02 * * * \\
(0.000)\end{array}$ & $\begin{array}{c}31.54 * * * \\
(0.000)\end{array}$ & $\begin{array}{c}22.58 * * * \\
(0.000)\end{array}$ \\
\hline $\begin{array}{l}\text { F-test for all education } \\
\text { dummies }\end{array}$ & 0.42 & 0.31 & 0.14 & 0.52 & 0.64 & 1.27 \\
\hline (p-value) & $(0.737)$ & $(0.820)$ & $(0.938)$ & $(0.672)$ & $(0.588)$ & $(0.289)$ \\
\hline $\begin{array}{l}\text { F-test for all log pce } \\
\text { splines }\end{array}$ & 0.59 & 0.54 & 0.32 & 0.66 & 0.76 & 0.67 \\
\hline (p-value) & $(0.556)$ & $(0.584)$ & $(0.724)$ & $(0.517)$ & $(0.468)$ & $(0.512)$ \\
\hline $\begin{array}{l}\text { F-test for all location } \\
\text { dummies }\end{array}$ & & 0.17 & $1.59 * * *$ & & 0.42 & $1.33^{* *}$ \\
\hline (p-value) & & $(0.917)$ & $(0.001)$ & & $(0.741)$ & $(0.028)$ \\
\hline Observations & 927 & 927 & 927 & 928 & 928 & 928 \\
\hline
\end{tabular}

Robust standard errors in parentheses, all clustered at community level.

$* \mathrm{p}<.1 * * \mathrm{p}<.05 * * * \mathrm{p}<.01$.

log pce (>median, marginal) represents the change in the slope from the interval for log pce below the median, see footnote 9 . 
Table 5. Under-diagnosis of hypertension and percentage taking medication or treatment, by age and sex

\begin{tabular}{|c|c|c|c|c|}
\hline & \multicolumn{2}{|c|}{ Men } & \multicolumn{2}{|c|}{ Women } \\
\hline & $\%$ & $N$ & $\%$ & $N$ \\
\hline \multicolumn{5}{|c|}{ Under-diagnosis } \\
\hline $45-54$ & $\begin{array}{l}47.7 \\
(7.9)\end{array}$ & 92 & $\begin{array}{l}41.9 \\
(5.4)\end{array}$ & 136 \\
\hline $55-64$ & $\begin{array}{l}48.3 \\
(5.9)\end{array}$ & 124 & $\begin{array}{l}34.9 \\
(4.9)\end{array}$ & 163 \\
\hline $65-74$ & $\begin{array}{l}44.1 \\
(6.1)\end{array}$ & 107 & $\begin{array}{l}51.2 \\
(5.0)\end{array}$ & 121 \\
\hline $75+$ & $\begin{array}{l}45.7 \\
(9.9)\end{array}$ & 45 & $\begin{array}{l}41.6 \\
(7.7)\end{array}$ & 59 \\
\hline Total (45+) & $\begin{array}{l}46.6 \\
(3.8)\end{array}$ & 368 & $\begin{array}{l}41.7 \\
(2.9)\end{array}$ & 479 \\
\hline \multicolumn{5}{|c|}{ Percentage taking medication or treatment } \\
\hline $45-54$ & $\begin{array}{l}63.4 \\
11.7\end{array}$ & 37 & $\begin{array}{c}70.4 \\
7.9\end{array}$ & 67 \\
\hline $55-64$ & $\begin{array}{l}83.2 \\
(5.3)\end{array}$ & 50 & $\begin{array}{l}81.5 \\
(4.2)\end{array}$ & 91 \\
\hline $65-74$ & $\begin{array}{c}71.2 \\
7.4\end{array}$ & 59 & $\begin{array}{l}83.7 \\
(5.8)\end{array}$ & 61 \\
\hline $75+$ & $\begin{array}{c}62.6 \\
(10.3)\end{array}$ & 25 & $\begin{array}{l}85.5 \\
(5.5)\end{array}$ & 35 \\
\hline Total $\left(45^{+}\right)$ & $\begin{array}{l}71.3 \\
(3.6)\end{array}$ & 171 & $\begin{array}{l}79.5 \\
(3.1)\end{array}$ & 254 \\
\hline
\end{tabular}

Standard errors in parentheses

Sample is those measured and diagnosed with hypertension. 
Table 6. Regressions for the under-diagnosis of hypertension

\begin{tabular}{|c|c|c|c|c|c|c|}
\hline & \multicolumn{3}{|c|}{ All Men } & \multicolumn{3}{|c|}{ All Women } \\
\hline & (1) & (2) & (3) & $(1)$ & $(2)$ & 3) \\
\hline Aged 55-64 & $\begin{array}{l}-0.120^{*} \\
(0.062)\end{array}$ & $\begin{array}{l}-0.120^{*} \\
(0.061)\end{array}$ & $\begin{array}{c}-0.165^{* *} \\
(0.081)\end{array}$ & $\begin{array}{l}-0.109^{*} \\
(0.059)\end{array}$ & $\begin{array}{l}-0.103^{*} \\
(0.058)\end{array}$ & $\begin{array}{l}-0.063 \\
(0.071)\end{array}$ \\
\hline Aged 65-74 & $\begin{array}{l}-0.185^{* *} \\
(0.073)\end{array}$ & $\begin{array}{c}-0.171^{* *} \\
(0.071)\end{array}$ & $\begin{array}{c}-0.201 * * \\
(0.093)\end{array}$ & $\begin{array}{l}-0.054 \\
(0.055)\end{array}$ & $\begin{array}{l}-0.038 \\
(0.055)\end{array}$ & $\begin{array}{l}-0.021 \\
(0.061)\end{array}$ \\
\hline Aged 75 and over & $\begin{array}{l}-0.208^{* *} \\
(0.101)\end{array}$ & $\begin{array}{l}-0.181^{*} \\
(0.101)\end{array}$ & $\begin{array}{l}-0.146 \\
(0.129)\end{array}$ & $\begin{array}{l}-0.127 \\
(0.085)\end{array}$ & $\begin{array}{l}-0.091 \\
(0.084)\end{array}$ & $\begin{array}{l}-0.054 \\
(0.097)\end{array}$ \\
\hline Can read and write & $\begin{array}{l}-0.110 \\
(0.075)\end{array}$ & $\begin{array}{l}-0.089 \\
(0.074)\end{array}$ & $\begin{array}{l}-0.073 \\
(0.090)\end{array}$ & $\begin{array}{l}-0.153^{* * *} \\
(0.056)\end{array}$ & $\begin{array}{l}-0.114^{* *} \\
(0.056)\end{array}$ & $\begin{array}{l}-0.084 \\
(0.065)\end{array}$ \\
\hline Finished primary & $\begin{array}{l}-0.050 \\
(0.066)\end{array}$ & $\begin{array}{l}-0.040 \\
(0.065)\end{array}$ & $\begin{array}{c}0.003 \\
(0.075)\end{array}$ & $\begin{array}{l}-0.255^{* * *} \\
(0.074)\end{array}$ & $\begin{array}{l}-0.221^{* * *} \\
(0.072)\end{array}$ & $\begin{array}{l}-0.156 \\
(0.100)\end{array}$ \\
\hline Junior high and above & $\begin{array}{l}-0.160^{*} \\
(0.083)\end{array}$ & $\begin{array}{l}-0.155^{*} \\
(0.086)\end{array}$ & $\begin{array}{l}-0.178^{*} \\
(0.093)\end{array}$ & $\begin{array}{c}-0.189 * * \\
(0.090)\end{array}$ & $\begin{array}{l}-0.153 \\
(0.093)\end{array}$ & $\begin{array}{l}-0.064 \\
(0.114)\end{array}$ \\
\hline log pce (< median) & $\begin{array}{l}-0.052 * \\
(0.029)\end{array}$ & $\begin{array}{l}-0.029 \\
(0.035)\end{array}$ & $\begin{array}{l}-0.025 \\
(0.049)\end{array}$ & $\begin{array}{l}-0.017 \\
(0.024)\end{array}$ & $\begin{array}{l}-0.005 \\
(0.025)\end{array}$ & $\begin{array}{c}0.009 \\
(0.033)\end{array}$ \\
\hline $\begin{array}{l}\log \text { pce (> median, } \\
\text { marginal) }\end{array}$ & 0.043 & 0.085 & 0.114 & 0.002 & 0.016 & 0.009 \\
\hline & $(0.079)$ & $(0.082)$ & $(0.089)$ & $(0.063)$ & $(0.062)$ & $(0.079)$ \\
\hline Rural Zhejiang & & $\begin{array}{c}0.071 \\
(0.073)\end{array}$ & & & $\begin{array}{c}0.023 \\
(0.058)\end{array}$ & \\
\hline Urban Gansu & & $\begin{array}{c}0.061 \\
(0.078)\end{array}$ & & & $\begin{array}{l}-0.005 \\
(0.056)\end{array}$ & \\
\hline Rural Gansu & & $\begin{array}{c}0.224 * * * \\
(0.069)\end{array}$ & & & $\begin{array}{c}0.165^{* * *} \\
(0.062)\end{array}$ & \\
\hline Community FE & NO & NO & YES & NO & NO & YES \\
\hline $\begin{array}{l}\text { F-test for all age dummies } \\
\text { (p-value) }\end{array}$ & $\begin{array}{l}2.73^{* *} \\
(0.049)\end{array}$ & $\begin{array}{l}2.49 * \\
(0.066)\end{array}$ & $\begin{array}{c}1.98 \\
(0.123)\end{array}$ & $\begin{array}{c}1.33 \\
(0.270)\end{array}$ & $\begin{array}{c}1.08 \\
(0.361)\end{array}$ & $\begin{array}{c}0.28 \\
(0.836)\end{array}$ \\
\hline $\begin{array}{l}\text { F-test for all education } \\
\text { dummies } \\
\text { (p-value) }\end{array}$ & $\begin{array}{c}1.37 \\
(0.259)\end{array}$ & $\begin{array}{c}1.18 \\
(0.322)\end{array}$ & $\begin{array}{c}1.60 \\
(0.194)\end{array}$ & $\begin{array}{l}5.40 * * * \\
(0.002)\end{array}$ & $\begin{array}{l}4.05^{* * *} \\
(0.010)\end{array}$ & $\begin{array}{c}1.08 \\
(0.361)\end{array}$ \\
\hline $\begin{array}{l}\text { F-test for all log pce } \\
\text { splines } \\
\text { (p-value) }\end{array}$ & $\begin{array}{c}1.96 \\
(0.147)\end{array}$ & $\begin{array}{c}0.56 \\
(0.571)\end{array}$ & $\begin{array}{c}0.89 \\
(0.416)\end{array}$ & $\begin{array}{c}0.38 \\
(0.687)\end{array}$ & $\begin{array}{c}0.03 \\
(0.968)\end{array}$ & $\begin{array}{c}0.12 \\
(0.887)\end{array}$ \\
\hline $\begin{array}{l}\text { F-test for all location } \\
\text { dummies } \\
\text { (p-value) }\end{array}$ & & $\begin{array}{l}3.82 * * \\
(0.013)\end{array}$ & $\begin{array}{l}1.46^{* *} \\
(0.024) \\
\end{array}$ & & $\begin{array}{l}2.80 * * \\
(0.045) \\
\end{array}$ & $\begin{array}{l}1.41^{* *} \\
(0.026) \\
\end{array}$ \\
\hline Observations & 366 & 366 & 366 & 477 & 477 & 477 \\
\hline
\end{tabular}

Robust standard errors in parentheses, all clustered at community level.

$* \mathrm{p}<.1 * * \mathrm{p}<.05 * * * \mathrm{p}<.01$. log pce (>median, marginal) represents the change in the slope from the interval for log pce below the median, see footnote 9 . 
Table 7. Regressions for the number of difficulties in ADLs

\begin{tabular}{|c|c|c|c|c|c|c|}
\hline & \multicolumn{3}{|c|}{ All Men } & \multicolumn{3}{|c|}{ All Women } \\
\hline & (1) & $(2)$ & (3) & (1) & $(2)$ & (3) \\
\hline Aged 55-64 & $\begin{array}{c}0.152^{* * *} \\
(0.033)\end{array}$ & $\begin{array}{c}0.149 * * * \\
(0.033)\end{array}$ & $\begin{array}{c}0.178 * * * \\
(0.049)\end{array}$ & $\begin{array}{l}0.074^{*} \\
(0.041)\end{array}$ & $\begin{array}{c}0.064 \\
(0.041)\end{array}$ & $\begin{array}{c}0.050 \\
(0.048)\end{array}$ \\
\hline Aged 65-74 & $\begin{array}{c}0.188 * * * \\
(0.059)\end{array}$ & $\begin{array}{c}0.177^{* * *} \\
(0.055)\end{array}$ & $\begin{array}{l}0.212 * * * \\
(0.061)\end{array}$ & $\begin{array}{c}0.263^{* *} \\
(0.101)\end{array}$ & $\begin{array}{c}0.268 * * * \\
(0.101)\end{array}$ & $\begin{array}{c}0.269 * * * \\
(0.101)\end{array}$ \\
\hline Aged 75 and over & $\begin{array}{c}0.831^{* * *} \\
(0.167)\end{array}$ & $\begin{array}{c}0.861^{* * * *} \\
(0.163)\end{array}$ & $\begin{array}{c}0.924^{* * *} \\
(0.172)\end{array}$ & $\begin{array}{c}0.687 * * * \\
(0.142)\end{array}$ & $\begin{array}{c}0.748 * * * \\
(0.135)\end{array}$ & $\begin{array}{c}0.786 * * * \\
(0.148)\end{array}$ \\
\hline Can read and write & $\begin{array}{l}-0.084 \\
(0.066)\end{array}$ & $\begin{array}{l}-0.044 \\
(0.065)\end{array}$ & $\begin{array}{l}-0.013 \\
(0.066)\end{array}$ & $\begin{array}{c}-0.137 * * \\
(0.065)\end{array}$ & $\begin{array}{l}-0.044 \\
(0.066)\end{array}$ & $\begin{array}{l}-0.015 \\
(0.067)\end{array}$ \\
\hline Finished primary & $\begin{array}{l}-0.066 \\
(0.072)\end{array}$ & $\begin{array}{l}-0.060 \\
(0.072)\end{array}$ & $\begin{array}{l}-0.039 \\
(0.073)\end{array}$ & $\begin{array}{l}-0.107^{*} \\
(0.058)\end{array}$ & $\begin{array}{l}-0.037 \\
(0.058)\end{array}$ & $\begin{array}{l}-0.027 \\
(0.068)\end{array}$ \\
\hline Junior high and above & $\begin{array}{l}-0.055 \\
(0.073)\end{array}$ & $\begin{array}{l}-0.097 \\
(0.078)\end{array}$ & $\begin{array}{l}-0.098 \\
(0.092)\end{array}$ & $\begin{array}{l}-0.106^{*} \\
(0.064)\end{array}$ & $\begin{array}{l}-0.100 \\
(0.066)\end{array}$ & $\begin{array}{l}-0.037 \\
(0.085)\end{array}$ \\
\hline log pce (< median) & $\begin{array}{l}-0.068 \\
(0.046)\end{array}$ & $\begin{array}{l}-0.042 \\
(0.048)\end{array}$ & $\begin{array}{l}-0.052 \\
(0.050)\end{array}$ & $\begin{array}{c}0.016 \\
(0.035)\end{array}$ & $\begin{array}{c}0.046 \\
(0.033)\end{array}$ & $\begin{array}{c}0.043 \\
(0.036)\end{array}$ \\
\hline $\begin{array}{l}\text { log pce (> median, } \\
\text { marginal) }\end{array}$ & $\begin{array}{c}0.068 \\
(0.080)\end{array}$ & $\begin{array}{c}0.087 \\
(0.079)\end{array}$ & $\begin{array}{c}0.101 \\
(0.083)\end{array}$ & $\begin{array}{l}-0.078 \\
(0.067)\end{array}$ & $\begin{array}{l}-0.041 \\
(0.064)\end{array}$ & $\begin{array}{l}-0.042 \\
(0.073)\end{array}$ \\
\hline Rural Zhejiang & & $\begin{array}{c}0.023 \\
(0.064)\end{array}$ & & & $\begin{array}{l}-0.054 \\
(0.062)\end{array}$ & \\
\hline Urban Gansu & & $\begin{array}{c}0.284 * * * \\
(0.087)\end{array}$ & & & $\begin{array}{l}0.187 * * \\
(0.079)\end{array}$ & \\
\hline Rural Gansu & & $\begin{array}{c}0.215^{* * *} \\
(0.067)\end{array}$ & & & $\begin{array}{c}0.356 * * * \\
(0.075)\end{array}$ & \\
\hline Community FE & NO & NO & YES & NO & NO & YES \\
\hline $\begin{array}{l}\text { F-test for all age dummies } \\
\text { (p-value) }\end{array}$ & $\begin{array}{c}14.69 * * * \\
(0.000)\end{array}$ & $\begin{array}{c}15.67 * * * \\
(0.000)\end{array}$ & $\begin{array}{c}13.60 * * * \\
(0.000)\end{array}$ & $\begin{array}{l}9.84 * * * \\
(0.000)\end{array}$ & $\begin{array}{c}12.24 * * * \\
(0.000)\end{array}$ & $\begin{array}{c}10.80^{* * *} \\
(0.000)\end{array}$ \\
\hline $\begin{array}{l}\text { F-test for all education } \\
\text { dummies } \\
\text { (p-value) }\end{array}$ & $\begin{array}{c}0.58 \\
(0.628)\end{array}$ & $\begin{array}{c}0.55 \\
(0.648)\end{array}$ & $\begin{array}{c}0.61 \\
(0.612)\end{array}$ & $\begin{array}{c}1.98 \\
(0.122)\end{array}$ & $\begin{array}{c}0.76 \\
(0.519)\end{array}$ & $\begin{array}{c}0.08 \\
(0.972)\end{array}$ \\
\hline $\begin{array}{l}\text { F-test for all log pce } \\
\text { splines } \\
\text { (p-value) }\end{array}$ & $\begin{array}{c}1.23 \\
(0.297)\end{array}$ & $\begin{array}{c}0.60 \\
(0.549)\end{array}$ & $\begin{array}{c}0.76 \\
(0.472)\end{array}$ & $\begin{array}{c}0.85 \\
(0.431)\end{array}$ & $\begin{array}{c}1.11 \\
(0.334)\end{array}$ & $\begin{array}{c}0.78 \\
(0.462)\end{array}$ \\
\hline $\begin{array}{l}\text { F-test for all location } \\
\text { dummies } \\
\text { (p-value) }\end{array}$ & & $\begin{array}{l}5.28 * * * \\
(0.002)\end{array}$ & $\begin{array}{l}1.26 * \\
(0.052)\end{array}$ & & $\begin{array}{c}15.05^{* * * *} \\
(0.000)\end{array}$ & $\begin{array}{l}1.76^{* * *} \\
(0.000)\end{array}$ \\
\hline Observations & 1250 & 1250 & 1250 & 1225 & 1225 & 1225 \\
\hline
\end{tabular}

Robust standard errors in parentheses, all clustered at community level.

$* \mathrm{p}<.1 * * \mathrm{p}<.05 * * * \mathrm{p}<.01$.

log pce (>median, marginal) represents the change in the slope from the interval for log pce below the median, see footnote 9 . 
Table 8. Regressions for the number of difficulties in IADLs

\begin{tabular}{|c|c|c|c|c|c|c|}
\hline & \multicolumn{3}{|c|}{ All Men } & \multicolumn{3}{|c|}{ All Women } \\
\hline & $(1)$ & $(2)$ & (3) & $(1)$ & $(2)$ & (3) \\
\hline Aged 55-64 & $\begin{array}{l}0.226 * * * \\
(0.056)\end{array}$ & $\begin{array}{c}0.227 * * * \\
(0.057)\end{array}$ & $\begin{array}{l}0.290 * * * \\
(0.081)\end{array}$ & $\begin{array}{l}0.186 * * * \\
(0.066)\end{array}$ & $\begin{array}{l}0.141^{* *} \\
(0.062)\end{array}$ & $\begin{array}{l}0.135^{*} \\
(0.074)\end{array}$ \\
\hline Aged 65-74 & $\begin{array}{c}0.323 * * * \\
(0.082)\end{array}$ & $\begin{array}{c}0.342 * * * \\
(0.075)\end{array}$ & $\begin{array}{c}0.385 * * * \\
(0.086)\end{array}$ & $\begin{array}{c}0.600 * * * \\
(0.123)\end{array}$ & $\begin{array}{c}0.596 * * * \\
(0.107)\end{array}$ & $\begin{array}{c}0.621 * * * \\
(0.110)\end{array}$ \\
\hline Aged 75 and over & $\begin{array}{l}1.506 * * * \\
(0.245)\end{array}$ & $\begin{array}{l}1.601^{* * *} \\
(0.236)\end{array}$ & $\begin{array}{l}1.681^{* * *} \\
(0.255)\end{array}$ & $\begin{array}{l}1.261^{* * *} \\
(0.254)\end{array}$ & $\begin{array}{c}1.467 * * * \\
(0.236)\end{array}$ & $\begin{array}{l}1.412 * * * \\
(0.242)\end{array}$ \\
\hline Can read and write & $\begin{array}{l}-0.504^{* * *} \\
(0.101)\end{array}$ & $\begin{array}{l}-0.388 * * * \\
(0.095)\end{array}$ & $\begin{array}{l}-0.354 * * * \\
(0.099)\end{array}$ & $\begin{array}{l}-0.454^{* * *} \\
(0.115)\end{array}$ & $\begin{array}{l}-0.144 \\
(0.109)\end{array}$ & $\begin{array}{l}-0.112 \\
(0.114)\end{array}$ \\
\hline Finished primary & $\begin{array}{l}-0.423^{* * *} \\
(0.104)\end{array}$ & $\begin{array}{l}-0.385^{* * *} \\
(0.097)\end{array}$ & $\begin{array}{l}-0.384^{* * *} \\
(0.104)\end{array}$ & $\begin{array}{l}-0.506^{* * * *} \\
(0.112)\end{array}$ & $\begin{array}{l}-0.270 * * * \\
(0.081)\end{array}$ & $\begin{array}{c}-0.232 * * \\
(0.109)\end{array}$ \\
\hline Junior high and above & $\begin{array}{l}-0.423^{* * *} \\
(0.098)\end{array}$ & $\begin{array}{l}-0.488 * * * \\
(0.097)\end{array}$ & $\begin{array}{l}-0.460 * * * \\
(0.101)\end{array}$ & $\begin{array}{l}-0.525 * * * \\
(0.112)\end{array}$ & $\begin{array}{l}-0.511^{* * *} \\
(0.101)\end{array}$ & $\begin{array}{l}-0.406^{* * *} \\
(0.128)\end{array}$ \\
\hline log pce (< median) & $\begin{array}{l}-0.146^{* * *} \\
(0.054)\end{array}$ & $\begin{array}{l}-0.055 \\
(0.050)\end{array}$ & $\begin{array}{c}-0.062 \\
(0.049)\end{array}$ & $\begin{array}{c}-0.208^{* * *} \\
(0.069)\end{array}$ & $\begin{array}{c}-0.111^{*} \\
(0.057)\end{array}$ & $\begin{array}{l}-0.119 * \\
(0.065)\end{array}$ \\
\hline $\begin{array}{l}\log \text { pce }(>\text { median, } \\
\text { marginal })\end{array}$ & $\begin{array}{c}0.019 \\
(0.092)\end{array}$ & $\begin{array}{c}0.084 \\
(0.089)\end{array}$ & $\begin{array}{c}0.095 \\
(0.094)\end{array}$ & $\begin{array}{l}-0.063 \\
(0.130)\end{array}$ & $\begin{array}{c}0.112 \\
(0.104)\end{array}$ & $\begin{array}{c}0.129 \\
(0.119)\end{array}$ \\
\hline Rural Zhejiang & & $\begin{array}{c}0.059 \\
(0.075)\end{array}$ & & & $\begin{array}{c}0.052 \\
(0.074)\end{array}$ & \\
\hline Urban Gansu & & $\begin{array}{c}0.465^{* * *} \\
(0.114)\end{array}$ & & & $\begin{array}{c}0.786 * * * \\
(0.138)\end{array}$ & \\
\hline Rural Gansu & & $\begin{array}{c}0.706^{* * *} \\
(0.088)\end{array}$ & & & $\begin{array}{c}1.393 * * * \\
(0.101)\end{array}$ & \\
\hline Community FE & NO & NO & YES & NO & NO & YES \\
\hline $\begin{array}{l}\text { F-test for all age dummies } \\
\text { (p-value) }\end{array}$ & $\begin{array}{c}15.57 * * * \\
(0.000)\end{array}$ & $\begin{array}{c}17.61 * * * \\
(0.000)\end{array}$ & $\begin{array}{c}15.73 * * * \\
(0.000)\end{array}$ & $\begin{array}{c}12.86^{* * *} \\
(0.000)\end{array}$ & $\begin{array}{c}18.62 * * * \\
(0.000)\end{array}$ & $\begin{array}{c}18.76^{* * *} \\
(0.000)\end{array}$ \\
\hline $\begin{array}{l}\text { F-test for all education } \\
\text { dummies } \\
\text { (p-value) }\end{array}$ & $\begin{array}{l}8.64 * * * \\
(0.000)\end{array}$ & $\begin{array}{l}8.71^{* * *} \\
(0.000)\end{array}$ & $\begin{array}{l}7.63^{* * *} \\
(0.000)\end{array}$ & $\begin{array}{l}9.95 * * * \\
(0.000)\end{array}$ & $\begin{array}{l}9.41^{* * * *} \\
(0.000)\end{array}$ & $\begin{array}{l}3.54^{* *} \\
(0.018)\end{array}$ \\
\hline $\begin{array}{l}\text { F-test for all log pce } \\
\text { splines } \\
\text { (p-value) }\end{array}$ & $\begin{array}{l}6.73 * * * \\
(0.002)\end{array}$ & $\begin{array}{c}0.63 \\
(0.535)\end{array}$ & $\begin{array}{c}0.84 \\
(0.437)\end{array}$ & $\begin{array}{c}15.31 * * * \\
(0.000)\end{array}$ & $\begin{array}{c}1.98 \\
(0.144)\end{array}$ & $\begin{array}{c}1.70 \\
(0.188)\end{array}$ \\
\hline $\begin{array}{l}\text { F-test for all location } \\
\text { dummies } \\
\text { (p-value) }\end{array}$ & & $\begin{array}{c}23.81 * * * \\
(0.000)\end{array}$ & $\begin{array}{l}1.86 * * * \\
(0.000)\end{array}$ & & $\begin{array}{c}73.84 * * * \\
(0.000)\end{array}$ & $\begin{array}{c}3.90^{* * *} \\
(0.000)\end{array}$ \\
\hline Observations & 1167 & 1167 & 1167 & 1118 & 1118 & 1118 \\
\hline
\end{tabular}

Robust standard errors in parentheses, all clustered at community level.

$* \mathrm{p}<.1 * * \mathrm{p}<.05 * * * \mathrm{p}<.01$.

log pce (>median, marginal) represents the change in the slope from the interval for log pce below the median, see footnote 9 . 
Table 9. Regressions for CES-D 10

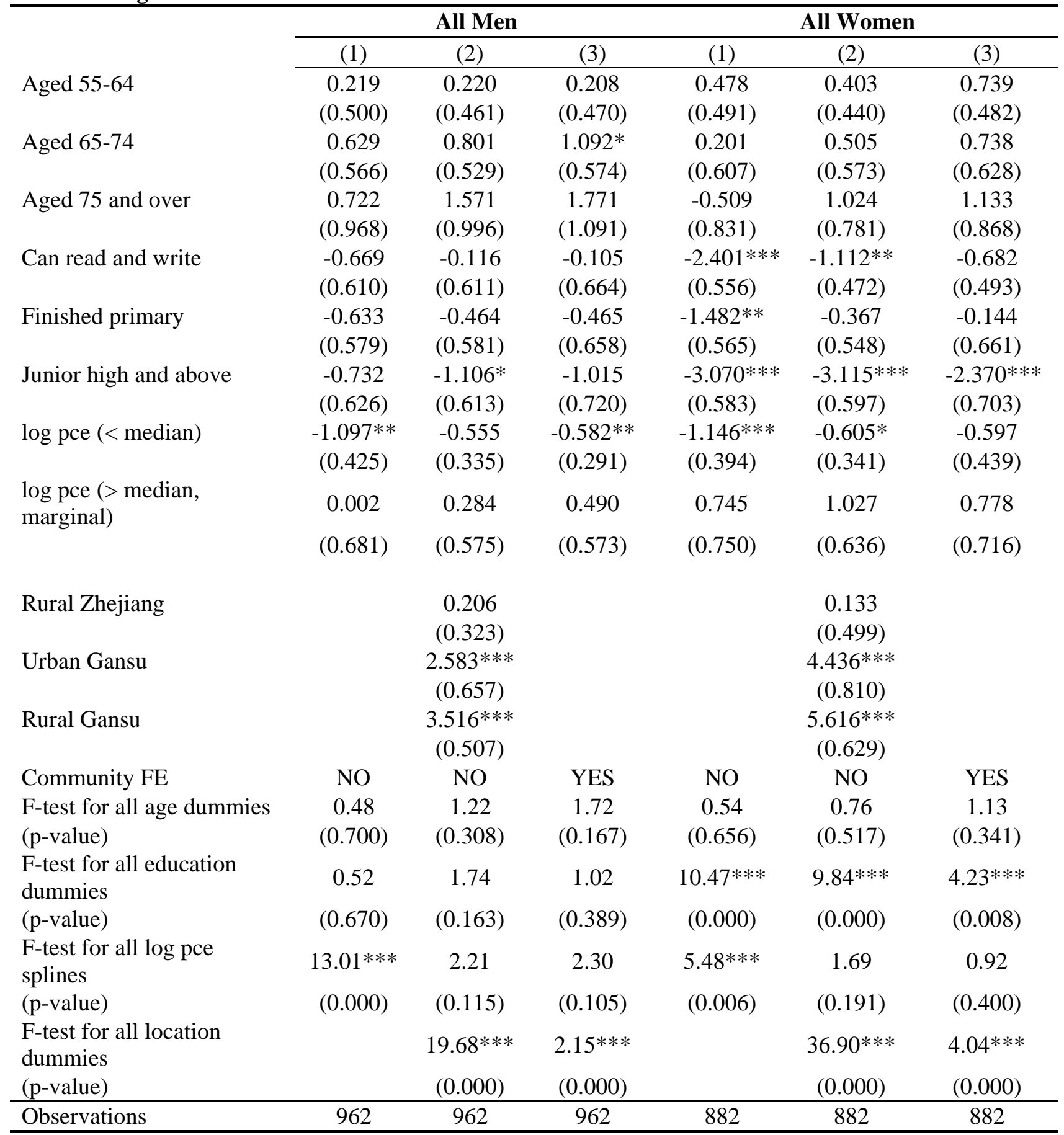

Robust standard errors in parentheses, all clustered at community level.

$* \mathrm{p}<.1 * * \mathrm{p}<.05 * * * \mathrm{p}<.01$.

log pce (>median, marginal) represents the change in the slope from the interval for log pce below the median, see footnote 9 . 
Table 10. Regressions for number of words recalled

\begin{tabular}{|c|c|c|c|c|c|c|}
\hline & \multicolumn{3}{|c|}{ All Men } & \multicolumn{3}{|c|}{ All Women } \\
\hline & $(1)$ & $(2)$ & (3) & $(1)$ & $(2)$ & $(3)$ \\
\hline Aged 55-64 & $\begin{array}{l}-0.106 \\
(0.147)\end{array}$ & $\begin{array}{l}-0.115 \\
(0.145)\end{array}$ & $\begin{array}{l}-0.201 \\
(0.164)\end{array}$ & $\begin{array}{l}-0.208^{*} \\
(0.111)\end{array}$ & $\begin{array}{l}-0.211 * \\
(0.111)\end{array}$ & $\begin{array}{l}-0.259 * \\
(0.132)\end{array}$ \\
\hline Aged 65-74 & $\begin{array}{l}-0.557 * * * \\
(0.131)\end{array}$ & $\begin{array}{l}-0.567 * * * \\
(0.126)\end{array}$ & $\begin{array}{l}-0.654^{* * *} \\
(0.133)\end{array}$ & $\begin{array}{l}-0.593^{* * *} \\
(0.173)\end{array}$ & $\begin{array}{l}-0.671^{* * *} \\
(0.175)\end{array}$ & $\begin{array}{l}-0.683 * * * \\
(0.219)\end{array}$ \\
\hline Aged 75 and over & $\begin{array}{l}-1.241^{* * *} \\
(0.251)\end{array}$ & $\begin{array}{l}-1.284^{* * *} \\
(0.245)\end{array}$ & $\begin{array}{l}-1.288^{* * *} \\
(0.247)\end{array}$ & $\begin{array}{l}-1.399 * * * \\
(0.285)\end{array}$ & $\begin{array}{l}-1.572^{* * *} \\
(0.279)\end{array}$ & $\begin{array}{l}-1.726^{* * * *} \\
(0.351)\end{array}$ \\
\hline Can read and write & $\begin{array}{c}0.580^{* * *} \\
(0.162)\end{array}$ & $\begin{array}{c}0.615^{* * *} \\
(0.166)\end{array}$ & $\begin{array}{c}0.675^{* * *} \\
(0.178)\end{array}$ & $\begin{array}{c}0.590 * * * \\
(0.161)\end{array}$ & $\begin{array}{c}0.451^{* * *} \\
(0.158)\end{array}$ & $\begin{array}{l}0.348 * \\
(0.189)\end{array}$ \\
\hline Finished primary & $\begin{array}{c}0.765 * * * \\
(0.149)\end{array}$ & $\begin{array}{c}0.793 * * * \\
(0.147)\end{array}$ & $\begin{array}{c}0.875^{* * *} \\
(0.170)\end{array}$ & $\begin{array}{c}0.823 * * * \\
(0.169)\end{array}$ & $\begin{array}{c}0.659 * * * \\
(0.159)\end{array}$ & $\begin{array}{c}0.628 * * * \\
(0.198)\end{array}$ \\
\hline Junior high and above & $\begin{array}{c}1.406^{* * *} \\
(0.157)\end{array}$ & $\begin{array}{c}1.405^{* * *} \\
(0.154)\end{array}$ & $\begin{array}{c}1.402^{* * *} \\
(0.171)\end{array}$ & $\begin{array}{c}1.738 * * * \\
(0.171)\end{array}$ & $\begin{array}{c}1.614 * * * \\
(0.169)\end{array}$ & $\begin{array}{c}1.476^{* * *} \\
(0.223)\end{array}$ \\
\hline log pce (< median) & $\begin{array}{c}0.285^{* * * *} \\
(0.088)\end{array}$ & $\begin{array}{c}0.266 * * * \\
(0.078)\end{array}$ & $\begin{array}{c}0.277 * * * \\
(0.086)\end{array}$ & $\begin{array}{c}0.214^{* *} \\
(0.099)\end{array}$ & $\begin{array}{c}0.121 \\
(0.093)\end{array}$ & $\begin{array}{c}0.022 \\
(0.122)\end{array}$ \\
\hline $\begin{array}{l}\log \text { pce }(>\text { median, } \\
\text { marginal })\end{array}$ & $\begin{array}{l}-0.088 \\
(0.165)\end{array}$ & $\begin{array}{l}-0.158 \\
(0.169)\end{array}$ & $\begin{array}{l}-0.256 \\
(0.188)\end{array}$ & $\begin{array}{c}0.146 \\
(0.203)\end{array}$ & $\begin{array}{c}0.148 \\
(0.194)\end{array}$ & $\begin{array}{c}0.183 \\
(0.223)\end{array}$ \\
\hline Rural Zhejiang & & $\begin{array}{l}-0.538 * * * \\
(0.195)\end{array}$ & & & $\begin{array}{l}-0.073 \\
(0.165)\end{array}$ & \\
\hline Urban Gansu & & $\begin{array}{l}-0.195 \\
(0.197)\end{array}$ & & & $\begin{array}{l}-0.048 \\
(0.168)\end{array}$ & \\
\hline Rural Gansu & & $\begin{array}{c}-0.380 * * \\
(0.181)\end{array}$ & & & $\begin{array}{l}-0.720^{* * *} \\
(0.184)\end{array}$ & \\
\hline Community FE & NO & NO & YES & NO & NO & YES \\
\hline $\begin{array}{l}\text { F-test for all age dummies } \\
\text { (p-value) }\end{array}$ & $\begin{array}{c}12.30 * * * \\
(0.000)\end{array}$ & $\begin{array}{c}14.02 * * * \\
(0.000)\end{array}$ & $\begin{array}{c}15.38 * * * \\
(0.000)\end{array}$ & $\begin{array}{l}9.78^{* * *} \\
(0.000)\end{array}$ & $\begin{array}{c}12.67 * * * \\
(0.000)\end{array}$ & $\begin{array}{c}9.48^{* * *} \\
(0.000)\end{array}$ \\
\hline $\begin{array}{l}\text { F-test for all education } \\
\text { dummies } \\
\text { (p-value) }\end{array}$ & $\begin{array}{c}26.42 * * * \\
(0.000)\end{array}$ & $\begin{array}{c}27.46^{* * *} \\
(0.000)\end{array}$ & $\begin{array}{c}23.06 * * * \\
(0.000)\end{array}$ & $\begin{array}{c}35.00 * * * \\
(0.000)\end{array}$ & $\begin{array}{c}30.48 * * * \\
(0.000)\end{array}$ & $\begin{array}{c}14.79 * * * \\
(0.000)\end{array}$ \\
\hline $\begin{array}{l}\text { F-test for all log pce } \\
\text { splines } \\
\text { (p-value) }\end{array}$ & $\begin{array}{c}10.16^{* * * *} \\
(0.000)\end{array}$ & $\begin{array}{l}7.94 * * * \\
(0.001)\end{array}$ & $\begin{array}{l}6.11^{* * *} \\
(0.003)\end{array}$ & $\begin{array}{c}10.34 * * * \\
(0.000)\end{array}$ & $\begin{array}{l}4.52 * * \\
(0.013)\end{array}$ & $\begin{array}{c}1.22 \\
(0.301)\end{array}$ \\
\hline $\begin{array}{l}\text { F-test for all location } \\
\text { dummies } \\
\text { (p-value) }\end{array}$ & & $\begin{array}{l}2.80 * * \\
(0.044)\end{array}$ & $\begin{array}{l}2.73 * * * \\
(0.000)\end{array}$ & & $\begin{array}{l}6.75^{* * * *} \\
(0.000)\end{array}$ & $\begin{array}{l}3.02^{* * *} \\
(0.000)\end{array}$ \\
\hline Observations & 852 & 852 & 852 & 765 & 765 & 765 \\
\hline
\end{tabular}

Robust standard errors in parentheses, all clustered at community level.

$* \mathrm{p}<.1 * * \mathrm{p}<.05 * * * \mathrm{p}<.01$.

log pce (>median, marginal) represents the change in the slope from the interval for log pce below the median see footnote 9 . 
Table 11. Regressions for "not very likely" or "almost impossible" to reach 75

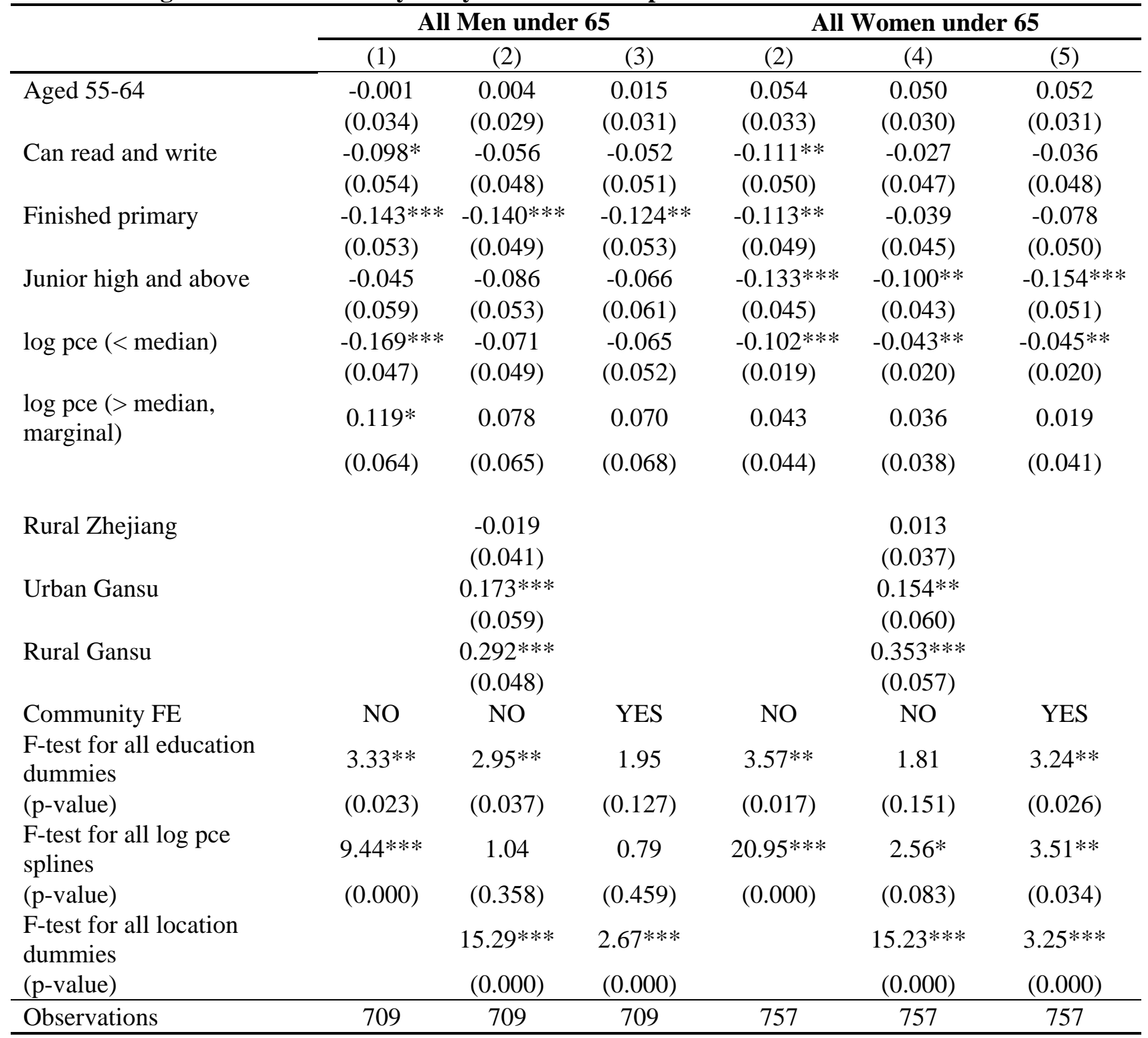

Robust standard errors in parentheses, all clustered at community level.

$* \mathrm{p}<.1 * * \mathrm{p}<.05 * * * \mathrm{p}<.01$.

log pce (>median, marginal) represents the change in the slope from the interval for log pce below the median, see footnote 9 . 
Table 12. Regressions for reported poor general health

\begin{tabular}{|c|c|c|c|c|c|c|}
\hline & \multicolumn{3}{|c|}{ Men } & \multicolumn{3}{|c|}{ Women } \\
\hline & $(1)$ & $(2)$ & (3) & $(1)$ & $(2)$ & $(3)$ \\
\hline Aged 55-64 & $\begin{array}{l}0.109 * * * \\
(0.029)\end{array}$ & $\begin{array}{l}0.110^{* * *} \\
(0.029)\end{array}$ & $\begin{array}{l}0.119 * * * \\
(0.031)\end{array}$ & $\begin{array}{l}0.064^{* *} \\
(0.031)\end{array}$ & $\begin{array}{l}0.059 * \\
(0.031)\end{array}$ & $\begin{array}{l}0.070 * * \\
(0.034)\end{array}$ \\
\hline Aged 65-74 & $\begin{array}{c}0.139 * * * \\
(0.034)\end{array}$ & $\begin{array}{c}0.146 * * * \\
(0.034)\end{array}$ & $\begin{array}{c}0.161 * * * \\
(0.038)\end{array}$ & $\begin{array}{c}0.023 \\
(0.038)\end{array}$ & $\begin{array}{c}0.033 \\
(0.035)\end{array}$ & $\begin{array}{c}0.038 \\
(0.039)\end{array}$ \\
\hline Aged 75 and over & $\begin{array}{c}0.164 * * * \\
(0.056)\end{array}$ & $\begin{array}{l}0.200 * * * \\
(0.059)\end{array}$ & $\begin{array}{c}0.202 * * * \\
(0.061)\end{array}$ & $\begin{array}{c}0.033 \\
(0.049)\end{array}$ & $\begin{array}{c}0.081 \\
(0.050)\end{array}$ & $\begin{array}{c}0.081 \\
(0.052)\end{array}$ \\
\hline Can read and write & $\begin{array}{l}-0.034 \\
(0.033)\end{array}$ & $\begin{array}{l}-0.007 \\
(0.033)\end{array}$ & $\begin{array}{c}0.007 \\
(0.036)\end{array}$ & $\begin{array}{c}-0.117 * * * \\
(0.035)\end{array}$ & $\begin{array}{l}-0.054 \\
(0.033)\end{array}$ & $\begin{array}{l}-0.018 \\
(0.035)\end{array}$ \\
\hline Finished primary & $\begin{array}{l}-0.067^{* *} \\
(0.034)\end{array}$ & $\begin{array}{l}-0.059 * \\
(0.035)\end{array}$ & $\begin{array}{r}-0.038 \\
(0.038)\end{array}$ & $\begin{array}{l}-0.077^{*} \\
(0.040)\end{array}$ & $\begin{array}{l}-0.018 \\
(0.038)\end{array}$ & $\begin{array}{l}-0.005 \\
(0.043)\end{array}$ \\
\hline Junior high and above & $\begin{array}{l}-0.042 \\
(0.034)\end{array}$ & $\begin{array}{l}-0.056 \\
(0.037)\end{array}$ & $\begin{array}{l}-0.032 \\
(0.043)\end{array}$ & $\begin{array}{l}-0.193^{* * *} \\
(0.040)\end{array}$ & $\begin{array}{c}-0.163^{* * *} \\
(0.041)\end{array}$ & $\begin{array}{l}-0.163^{* * *} \\
(0.048)\end{array}$ \\
\hline log pce (< median) & $\begin{array}{c}-0.025 \\
(0.028)\end{array}$ & $\begin{array}{c}0.001 \\
(0.029)\end{array}$ & $\begin{array}{c}0.012 \\
(0.031)\end{array}$ & $\begin{array}{l}-0.054 * * * \\
(0.017)\end{array}$ & $\begin{array}{c}-0.033 * * \\
(0.016)\end{array}$ & $\begin{array}{c}-0.037 * * \\
(0.016)\end{array}$ \\
\hline $\begin{array}{l}\log \text { pce }(>\text { median, } \\
\text { marginal) }\end{array}$ & $\begin{array}{l}-0.047 \\
(0.047)\end{array}$ & $\begin{array}{l}-0.026 \\
(0.046)\end{array}$ & $\begin{array}{l}-0.044 \\
(0.048)\end{array}$ & $\begin{array}{c}0.030 \\
(0.042)\end{array}$ & $\begin{array}{l}0.055 \\
(0.041)\end{array}$ & $\begin{array}{l}0.078 * \\
(0.040)\end{array}$ \\
\hline Rural Zhejiang & & $\begin{array}{c}0.045 \\
(0.030)\end{array}$ & & & $\begin{array}{c}0.033 \\
(0.050)\end{array}$ & \\
\hline Urban Gansu & & $\begin{array}{c}0.124 * * * \\
(0.043)\end{array}$ & & & $\begin{array}{l}0.111^{*} \\
(0.045)\end{array}$ & \\
\hline Rural Gansu & & $\begin{array}{c}0.193 * * * \\
(0.031)\end{array}$ & & & $\begin{array}{c}0.268 * * * \\
(0.040)\end{array}$ & \\
\hline Community FE & NO & NO & YES & NO & NO & YES \\
\hline $\begin{array}{l}\text { F-test for all age dummies } \\
\text { (p-value) }\end{array}$ & $\begin{array}{c}8.45^{* * *} \\
(0.000)\end{array}$ & $\begin{array}{l}9.48^{* * *} \\
(0.000)\end{array}$ & $\begin{array}{l}8.84 * * * \\
(0.000)\end{array}$ & $\begin{array}{c}1.39 \\
(0.252)\end{array}$ & $\begin{array}{c}1.67 \\
(0.179)\end{array}$ & $\begin{array}{c}1.88 \\
(0.138)\end{array}$ \\
\hline $\begin{array}{l}\text { F-test for all education } \\
\text { dummies } \\
\text { (p-value) }\end{array}$ & $\begin{array}{c}1.34 \\
(0.267)\end{array}$ & $\begin{array}{c}1.66 \\
(0.180)\end{array}$ & $\begin{array}{c}0.77 \\
(0.513)\end{array}$ & $\begin{array}{l}8.49 * * * \\
(0.000)\end{array}$ & $\begin{array}{l}5.61 * * * \\
(0.001)\end{array}$ & $\begin{array}{l}4.13^{* * *} \\
(0.009)\end{array}$ \\
\hline $\begin{array}{l}\text { F-test for all log pce } \\
\text { splines } \\
\text { (p-value) }\end{array}$ & $\begin{array}{l}6.19 * * * \\
(0.003)\end{array}$ & $\begin{array}{c}0.53 \\
(0.591)\end{array}$ & $\begin{array}{c}0.70 \\
(0.499)\end{array}$ & $\begin{array}{l}6.13^{* * *} \\
(0.003)\end{array}$ & $\begin{array}{c}2.24 \\
(0.113)\end{array}$ & $\begin{array}{l}3.17 * * \\
(0.046)\end{array}$ \\
\hline $\begin{array}{l}\text { F-test for all location } \\
\text { dummies } \\
\text { (p-value) }\end{array}$ & & $\begin{array}{c}13.55^{* * * *} \\
(0.000)\end{array}$ & $\begin{array}{l}1.50 * * * \\
(0.004)\end{array}$ & & $\begin{array}{c}18.03^{* * * *} \\
(0.000)\end{array}$ & $\begin{array}{l}2.31^{* * *} \\
(0.000)\end{array}$ \\
\hline Observations & 1108 & 1108 & 1108 & 1120 & 1120 & 1120 \\
\hline
\end{tabular}

Robust standard errors in parentheses all clustered at community level.

$* \mathrm{p}<.1 * * \mathrm{p}<.05 * * * \mathrm{p}<.01$.

log pce (>median, marginal) represents the change in the slope from the interval for log pce below the median, see footnote 9 . 
Table 13. Regressions for smoking: Men

\begin{tabular}{|c|c|c|c|c|}
\hline & \multicolumn{4}{|c|}{ current smoking } \\
\hline & $\begin{array}{c}\text { Ever } \\
\text { smoking }\end{array}$ & (1) & $(2)$ & (3) \\
\hline Aged 55-64 & $\begin{array}{l}-0.050 \\
(0.033)\end{array}$ & $\begin{array}{l}-0.089 * * \\
(0.037)\end{array}$ & $\begin{array}{l}-0.088 * * \\
(0.037)\end{array}$ & $\begin{array}{c}-0.077^{* *} \\
(0.038)\end{array}$ \\
\hline Aged 65-74 & $\begin{array}{c}0.129 * * * \\
(0.045)\end{array}$ & $\begin{array}{c}- \\
0.206^{* * *} \\
(0.046)\end{array}$ & $\begin{array}{c}-0.204 * * * \\
(0.046)\end{array}$ & $\begin{array}{c}-0.206 * * * \\
(0.050)\end{array}$ \\
\hline Aged 75 and over & $\begin{array}{c}-0.146 * * \\
(0.059)\end{array}$ & $\begin{array}{c}-0.296^{* * *} \\
(0.057)\end{array}$ & $\begin{array}{c}-0.298 * * * \\
(0.055)\end{array}$ & $\begin{array}{c}-0.270 * * * \\
(0.058)\end{array}$ \\
\hline Can read and write & $\begin{array}{l}0.077 * \\
(0.045)\end{array}$ & $\begin{array}{l}-0.005 \\
(0.044)\end{array}$ & $\begin{array}{l}-0.011 \\
(0.045)\end{array}$ & $\begin{array}{l}-0.003 \\
(0.048)\end{array}$ \\
\hline Finished primary & $\begin{array}{c}0.075 * \\
(0.040)\end{array}$ & $\begin{array}{r}0.008 \\
(0.046)\end{array}$ & $\begin{array}{c}0.007 \\
(0.046)\end{array}$ & $\begin{array}{c}0.019 \\
(0.051)\end{array}$ \\
\hline Junior high and above & $\begin{array}{c}0.068 \\
(0.045)\end{array}$ & $\begin{array}{c}0.011 \\
(0.047)\end{array}$ & $\begin{array}{c}0.019 \\
(0.047)\end{array}$ & $\begin{array}{r}0.017 \\
(0.050)\end{array}$ \\
\hline log pce (< median) & & $\begin{array}{l}0.045^{* *} \\
(0.019)\end{array}$ & $\begin{array}{l}0.043^{* *} \\
(0.018)\end{array}$ & $\begin{array}{l}0.044^{* *} \\
(0.019)\end{array}$ \\
\hline $\begin{array}{l}\log \text { pce }(>\text { median, } \\
\text { marginal) }\end{array}$ & & $\begin{array}{l}-0.020 \\
(0.043)\end{array}$ & $\begin{array}{l}-0.014 \\
(0.045)\end{array}$ & $\begin{array}{c}0.007 \\
(0.049)\end{array}$ \\
\hline Rural Zhejiang & & & $\begin{array}{c}0.046 \\
(0.055)\end{array}$ & \\
\hline Urban Gansu & & & $\begin{array}{l}-0.022 \\
(0.054)\end{array}$ & \\
\hline Rural Gansu & & & $\begin{array}{c}0.012 \\
(0.053)\end{array}$ & \\
\hline Community FE & NO & NO & NO & YES \\
\hline $\begin{array}{l}\text { F-test for all age dummies } \\
\text { (p-value) }\end{array}$ & $\begin{array}{c}3.45 \mathrm{II} \\
(0.020)\end{array}$ & $\begin{array}{c}11.12 * * * \\
(0.000)\end{array}$ & $\begin{array}{c}11.55^{* * *} \\
(0.000)\end{array}$ & $\begin{array}{c}9.83^{* * *} \\
(0.000)\end{array}$ \\
\hline $\begin{array}{l}\text { F-test for all education } \\
\text { dummies } \\
\text { (p-value) }\end{array}$ & $\begin{array}{c}1.40 \\
(0.248)\end{array}$ & $\begin{array}{c}0.04 \\
(0.988)\end{array}$ & $\begin{array}{c}0.12 \\
(0.945)\end{array}$ & $\begin{array}{c}0.09 \\
(0.964)\end{array}$ \\
\hline $\begin{array}{l}\text { F-test for all log pce } \\
\text { splines } \\
\text { (p-value) }\end{array}$ & & $\begin{array}{l}3.48^{* *} \\
(0.035)\end{array}$ & $\begin{array}{l}3.49 * * \\
(0.034)\end{array}$ & $\begin{array}{l}4.48 * * \\
(0.014)\end{array}$ \\
\hline $\begin{array}{l}\text { F-test for all location } \\
\text { dummies } \\
\text { (p-value) }\end{array}$ & & & $\begin{array}{c}0.47 \\
(0.701 \\
\end{array}$ & $\begin{array}{l}1.72 * * * \\
(0.000)\end{array}$ \\
\hline Observations & 1111 & 1111 & 1111 & 1111 \\
\hline
\end{tabular}

Robust standard errors in parentheses all clustered at community level.

$* \mathrm{p}<.1 * * \mathrm{p}<.05 * * * \mathrm{p}<.01$.

log pce (>median, marginal) represents the change in the slope from the interval for log pce below the median see footnote 9 . 